University of Nebraska - Lincoln

DigitalCommons@University of Nebraska - Lincoln

\title{
Root and crown rot pathogens found on dry beans grown in Mozambique
}

Suzana Vanessa Ismael Fernandes

G. Godoy-Lutz

Celestina Nhagupana Jochua

Carlos A. Urrea

Kent M. Eskridge

See next page for additional authors

Follow this and additional works at: https://digitalcommons.unl.edu/plantpathpapers

Part of the Other Plant Sciences Commons, Plant Biology Commons, and the Plant Pathology Commons

This Article is brought to you for free and open access by the Plant Pathology Department at DigitalCommons@University of Nebraska - Lincoln. It has been accepted for inclusion in Papers in Plant Pathology by an authorized administrator of DigitalCommons@University of Nebraska - Lincoln. 


\section{Authors}

Suzana Vanessa Ismael Fernandes; G. Godoy-Lutz; Celestina Nhagupana Jochua; Carlos A. Urrea; Kent M. Eskridge; James R, Steadman; and Joshua Herr 


\title{
Root and crown rot pathogens found on dry beans grown in Mozambique
}

\author{
Suzanna Fernandes, ${ }^{1,2}$ Graciela Godoy-Lutz, ${ }^{1,3}$ \\ Celestina Jochua, ${ }^{1,2}$ Carlos Urrea, ${ }^{4}$ Kent Eskridge, ${ }^{5}$ \\ James R. Steadman, ${ }^{1}$ and Joshua R. Herr ${ }^{1,6,7}$
}

Suzanna Fernandes and Graciela Godoy-Lutz contributed equally to this work.

1 Department of Plant Pathology, University of Nebraska-Lincoln, Lincoln, NE 68583, USA

2 Present address: Directorate of Agronomy and Natural Resources (DARN), The Agricultural Research Institute of Mozambique (IIAM), Maputo, Mozambique

3 Present address: Instituto Dominicano de Investigaciones Agropecurarias y Forestales (IDIAF), Santo Domingo, Dominican Republic

4 Department of Agronomy \& Horticulture, University of Nebraska-Lincoln, Lincoln, NE 68583, USA

5 Department of Statistics, University of Nebraska-Lincoln, Lincoln, NE 68583, USA

6 Center for Plant Science Innovation, University of Nebraska-Lincoln, Lincoln, NE 68588, USA

7 Genetics, Cell, and Molecular Biology Graduate Program, School of Biological Sciences, University of Nebraska, Lincoln, NE 68588, USA

Correspondence - Joshua R. Herr, jherr@unl.edu

Published in Tropical Plant Pathology 46 (2021), pp 294-310.

https://doi.org/10.1007/s40858-021-00422-8

Copyright (C) 2021 Sociedade Brasileira de Fitopatologia. Published by Springer Nature. Used by permission.

Submitted 16 March 2019; accepted 16 February 2021; published 25 March 2021. 


\begin{abstract}
Dry edible beans are a vital food source in Mozambique, East Africa-one that alleviates hunger and malnutrition and adds value to the economy. In recent years, root/ crown rot (RCR) pathogens have emerged as limiting constraints in dry bean production. Not much has been characterized concerning the causal agents of RCR in Mozambique. The purpose of this study was to identify the primary pathogen(s) associated with RCR dry bean samples collected at breeder nursery sites and farmer fields in Mozambique using molecular sequencing and culture-based methods. Sequencing revealed, not surprisingly, an increased diversity of fungal/oomycete operational taxonomic units when compared to culture-based methods of diversity. Species of Fusarium, mainly F. oxysporum, were the dominant taxa detected in RCR dry beans through sequencing the ITS rDNA region and partial EF-1 $\alpha$ gene. Collectively, 333 fungi and/ or Oomycetes were isolated in culture during the 2014-2015 growing seasons and tested for pathogenicity on healthy bean seedlings. Fusarium species were identified by both morphological and molecular characters. At least $60 \%$ of the isolates inoculated on common bean were recognized as potentially pathogenic. From both isolation frequency and pathogenicity testing, F. oxysporum and related species play an important role in the bean RCR complex. We found similar results from dry beans grown in the two main bean-growing regions of Mozambique. These findings will allow breeders to screen for resistance to F. oxysporum in greenhouse grown bean plants as well as within field grown bean cultivars.
\end{abstract}

Keywords: Soil-borne fungal pathogens, Fusarium, FTA® Cards, High-throughput sequencing, Bean root and crown rot, Macrophomina, Fusarium oxysporum

\title{
Introduction
}

Dry edible beans (Phaseolus vulgaris L.), with a yearly production harvest area of 100,000 ha, are one of the most important food sources in Mozambique (Wortmann et al. 1998). Beans provide an important source of dietary protein, micro-nutrients, and caloric intake for the people of Mozambique, as well as a crucial source of income for the small-scale farmers (Wortmann et al. 1998). Mozambique, which is located on the southeastern coast of Africa, has many challenges for bean production, due in large part to climate variation through cyclical drought and excessive rainfall and plant diseases are exacerbated these changes in climate (Walker et al. 2006). Consequently, diseases such as root/ crown rot (RCR) are emerging as limiting factors in bean production enhanced by changing environmental conditions (Farrow et al. 2011; Bodah 2017).

Bean RCR comprises a syndrome attributed to a suite of soil-borne pathogens. These pathogens may be reported either as individual strains 
or synergistic infections whose occurrence and severity varies by location, site-specific incidences, soil properties and nutrients, and/or other variable environmental conditions that contribute to disease propagation and spread (Rusuku et al. 1997; Wortmann et al. 1998; Farrow et al. 2011). Most species of soil-borne pathogens have been identified as causal agents using traditional culture methods and pathogenicity tests. The most relevant species reported in Mozambique are Fusarium solani (Mart.) Appel, Wollenv. F. sp. phaseoli (Burk.) Synd. \& Hans, F. oxysporum Schlecht. F. sp. phaseoli Kendrick \& Synder, Pythium spp., Rhizoctonia solani Kühn (teleomorph: Thanatephorus cucumeris (Tassi) Goid), Athelia rolfsii (Curzi) C.C. Tu \& Kimbr., and Macrophomina phaseolina (Tassi) Goid (Abawi 1989; Rusuku et al. 1997; Paparu et al. 2018). Recently, in eastern and southern Africa, species of Pythium have received more attention due to their higher prevalence over other pathogens in disease surveys (Nzungize et al. 2011a, Nzungize et al. 2011b). As a result, breeding programs in some countries have focused on only developing RCR resistance for Pythium species.

In Mozambique, there is limited information on the pathogenic species causing, or associated with, bean RCR symptoms. This is despite widespread disease occurrence in the Gurue and Chokwe provinces where beans are most consistently grown. The proper identification of the primary causal pathogen(s) can lead to better disease management strategies and may improve bean production due to the fact that yield loss has not been accurately calculated for each pathogen. Morphological features of pathogens cultured from infected plants provide important information for identification in the laboratory (Narayanasamy 2011), and live pathogenic specimens are vital for disease-resistance inoculations and greenhouse evaluations in breeding programs. In addition to traditional morphological characters, molecular methods, such as high-throughput sequencing, have become commonplace in pathogen detection and species identification (Herr et al. 2015; Hibbett et al. 2016). In the present study, we employed a suite of morphological and molecular identification techniques to identify the diversity of the predominant pathogen (or pathogens) in Mozambique that are associated with bean RCR. We additionally focused on the population structure of Fusarium oxysporum isolates recovered from the same bean RCR samples. 


\section{Materials and methods}

\section{Sample collection and processing}

We took advantage of collecting plants from a field test of four Andean Diversity Panels for Bean (Cichy et al. 2015). These panels were situated where root rot screening has already been in effect for at least a decade. The survey locations in the present study included the R10 (North West) region, which has the greatest levels of bean production, and is fed by rainfall; the R3 (South West) region where production is under dry winter irrigation nurseries; and lastly, from two farmer fields: R3 (Chokwe) and R10 (Gurue), respectively, from the Gaza and Zambesia provinces in well-studied agro-ecological zones (Wortmann et al. 1998). The sampling locations in 2014 and 2015 represented contrasting climatic and soil conditions (Fig. 1 and Table S-3). The essential differences of these conditions consisted the sampling locations of Chokwe, where the site is close to sea level, had organic matter-rich Salic Fluvisol soils and recognized as a semi-arid climate, and the sampling locations of Gurue, which is approximately $700 \mathrm{~m}$ above sea level, and consist of Ferrossols with less organic matter, and a slightly cooler climate due to the elevation gain of slightly more than $100 \mathrm{~m}$.

Within 30 days after bean plant emergence, we identified and sampled 88 bean plants with RCR symptoms (Fig. 1) along with a healthy control plant in close proximity, typically no more than $1 \mathrm{~m}$ away. Plants were harvested in the field, placed in a cooler with ice, and brought to the laboratory for processing. Soil and associated debris were removed from the plants and lesions (approximately 2-4 $\mathrm{mm}$ in size) at both the diseased and healthy interface (Fig. 2a) were extracted according to published protocols (Mukuma et al. 2020). Lesions of infected tissue were isolated, flash-frozen, and ground with a micro-pestle (Fig. 2b). Liquid extracts of the lesions were spotted onto the absorbent matrix of Whatman FTA $®$ Cards and matching tissue samples were placed in a coin envelope and labeled with the sample number, bean cultivar name, description of phenotypic symptoms, the location and dates of sampling, and any other field-related data taken during collection, such as unique climate and precipitation notes. 

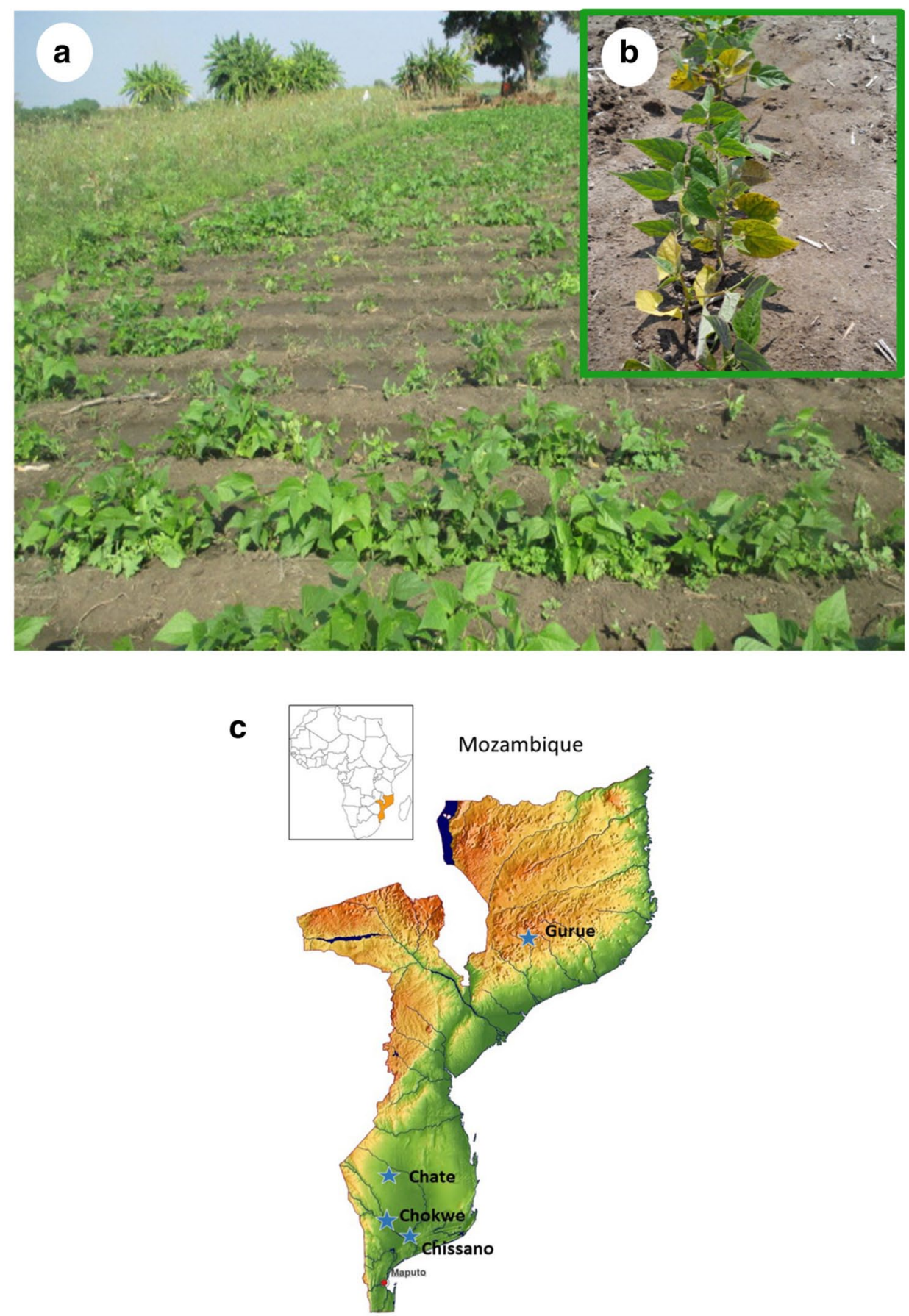

Fig. 1 (a) Bean field affected by root/crown rot (RCR) in Chokwe, Mozambique. (b) Inset photo of row of RCR and wilt of bean plants. (c) Topographical map of Mozambique with specific location on the continent of Africa and the general locations that were sampled in this study. 


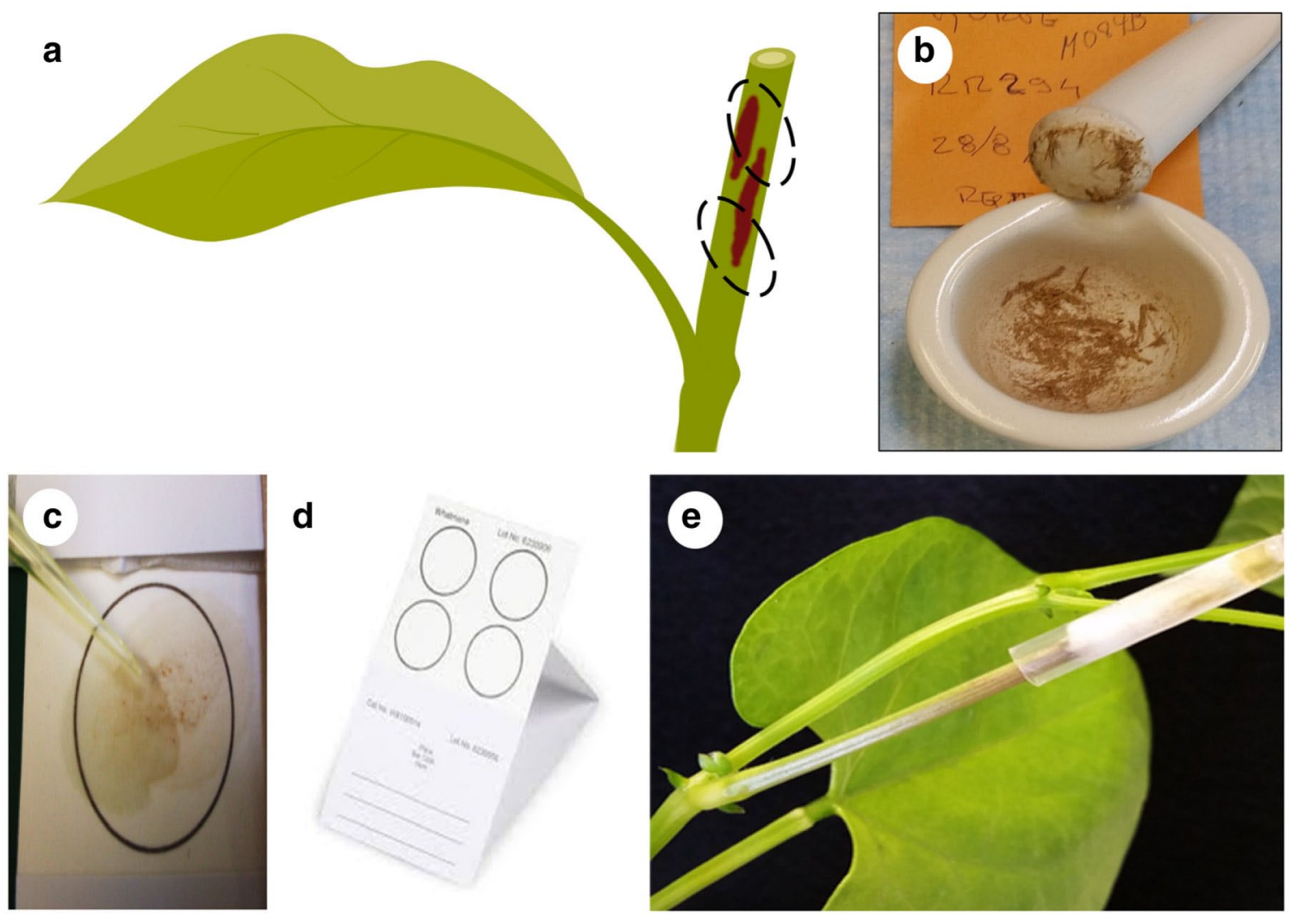

Fig. 2 (a) Schematic representation of typical bean plant showing infection site and location of where tissues were sampled. (b) Ground RCR tissue for DNA extraction. (c) Tissue extracts blotted onto FTA Card. (d) Entire FTA ® Card shipped to laboratory. (e) Photo of the pathogenicity test by the "straw method" conducted in the greenhouse.

\section{Fungal/Oomycete cultural isolation}

Small segments of 2-4 mm of the RCR diseased plant tissue were surface sterilized by immersing in $10 \% \mathrm{v} / \mathrm{v} \mathrm{NaOCI} /$ water for $15-30 \mathrm{~s}$, then transferring to $70 \%$ alcohol for $15-30 \mathrm{~s}$, and finally to a distilled water wash for 1-2 min. The infected segments of plant tissue were then blotted on sterile Whatman ${ }^{\mathrm{TM}}$ filter paper to air dry, and then transferred using sterile forceps onto $2 \%$ water agar where segments reached about 4 $\mathrm{mm}$ in length. After this growth period, the resulting isolate hyphae was transferred onto potato dextrose agar (PDA) to allow further growth. Within 2-4 days, 4-mm mycelial plugs were transferred to four PDA 

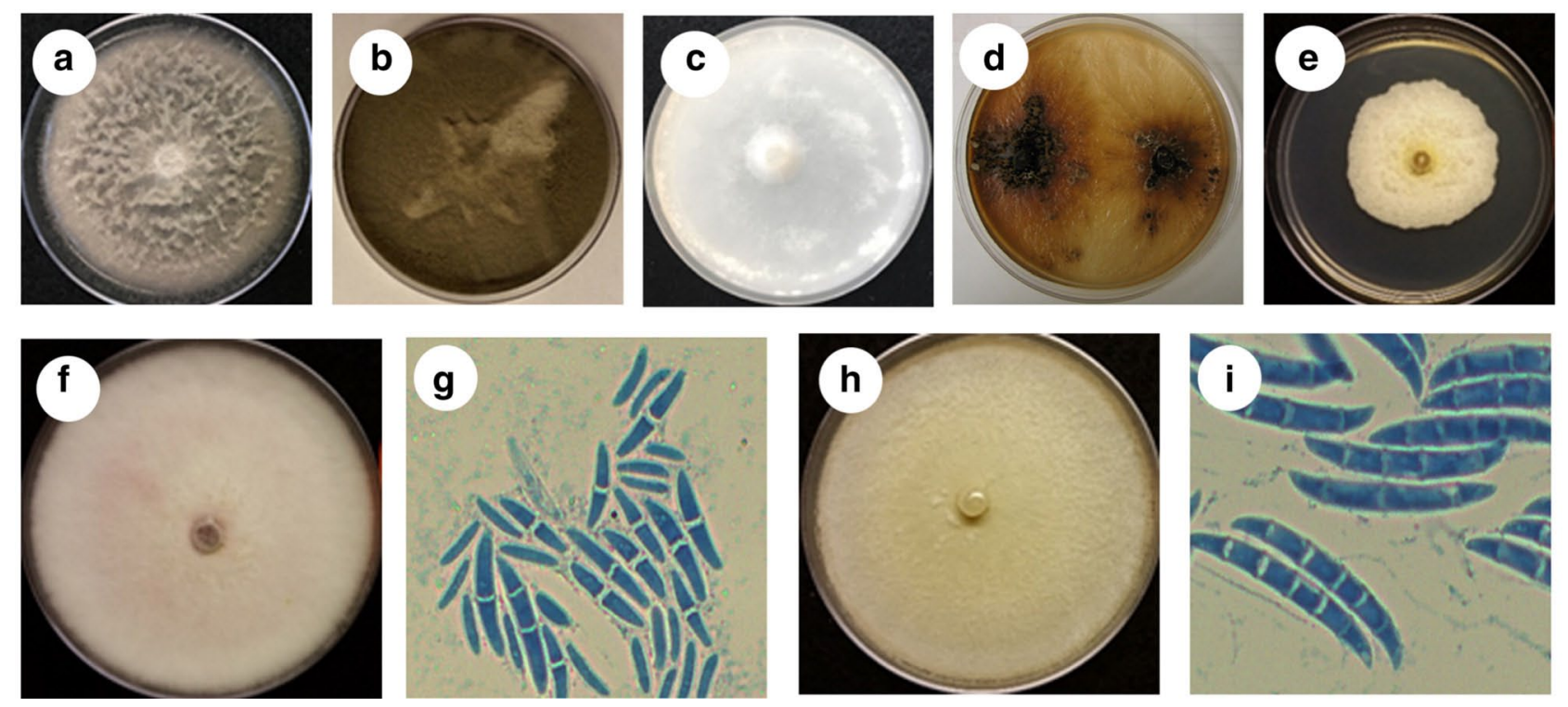

Fig. 3 Photos of Fungi and Oomycetes isolated in this study: (a) Macrophomina phaseolina; (b) Alternaria alternate; (c) Pythium ultimum; (d) Rhizoctonia solani; (e) Fusarium equiseti; (f) Fusarium oxysporum; (g) spores of Fusarium oxysporum stained with lactophenol cotton blue; (h) Fusarium solani; (i) spores of Fusarium solani stained with lactophenol cotton blue.

plates and one water agar (WA) plate for each isolate. These plates were used for morphological observations, future pathogenicity tests, and mycelial DNA extraction for subsequent nucleotide sequencing. Culture characteristics were examined across three different culture media: WA, PDA, and carnation leaf agar (CLA) (Fisher et al. 1982: Leslie and Summerell, 2006). The characteristics observed were growth pattern, colony texture and pigmentation, spore size and shape, and growth rate of the mycelial edge (Fig. 3). Mycelial plugs of a 6-mm diameter were taken from the WA colony edge of each isolate and transferred to PDA plates and incubated under continuous darkness for 9 days at 22$25^{\circ} \mathrm{C}$. Colony diameter was measured on the bottom of the plate. Colony texture and color on PDA were evaluated for each isolate. For fungi and Oomycetes, the genus and species names were assigned using several identification keys (Dhingra and Sinclair 1978; Dugan 2006; Watanabe 2010). Species of Fusarium were identified based on the color and growth pattern of colonies grown on PDA, then transferred to CLA for identification using dichotomous keys (Burgess et al. 1994; Leslie and 
Summerell 2006) focusing on characters such as the size and morphology of phialides, macro- and micro-conidia, and chlamydospores. Fusarium isolates grown on CLA media at $20-24{ }^{\circ} \mathrm{C}$ with a 12 -h light/12-h dark regime for 10 days sporulated on CLA, and spore masses growing on the leaf surface were transferred to a blue drop of lactophenol cotton blue on a glass slide to observe spore size and shape. Diagnostic characters were then photographed using a compound light microscope mounted with a Motic camera (Motic North America, British Columbia, Canada) at $\times 40$ magnification.

\section{DNA extraction from FTA® Cards and plant tissue}

In order to extract DNA from field collected samples, the Whatman FTA $®$ Cards and matching tissue samples were sent to the laboratory located at the Department of Plant Pathology at the University of Nebraska-Lincoln, NE, USA, under the USDA-APHIS Permit P526P-17-02138 issued to J.R. Steadman. Samples waiting to be processed were kept in a desiccant chamber at room temperature. Due to a small number of samples from the Whatman FTA $®$ Cards that we were not able to acquire enough DNA for sequencing, as well as the overall proximity and similarities of some of the sampling locations, we evaluated all the data from the closely located geographic locations Chato and Chissano (analyzed further as the Gurue (R10) growing region) along with the larger number of samples from Chokwe (R3) growing region (Fig. 1).

Genomic DNA from the FTA $®$ Cards was recovered from an excised 1- $\mathrm{cm}^{2}$ section of the Card by incubation in 200-300 $\mu$ l of TRIS-EDTA buffer solution (Fluka Analytical, Sigma-Aldrich Co., St. Louis, MO, USA) at 4 ${ }^{\circ} \mathrm{C}$ overnight. After this incubation, $100 \mu \mathrm{l}$ of the buffer solution was used for DNA extraction with the PowerClean Pro DNA Cleanup Kit (Catalog No.12997-50 MO BIO Laboratories, Inc., Carlsbad, CA, USA). Genomic DNA was extracted from $100 \mathrm{mg}$ of cryogenic ground RCR diseased plant tissue or isolate mycelia using the PowerPlant Pro DNA isolation kit (Catalog No. 13400-50, MO BIO Laboratories Inc., Carlsbad, CA, USA). Concentration and purity of total DNA from each sample was determined using a DeNovix DS-11 Nanodrop Spectrophotometer (DeNovix Inc., Wilmington, DE). Genomic DNA from the extraction process was stored at $-20{ }^{\circ} \mathrm{C}$ until sequencing. 


\section{PCR amplification and DNA sequencing}

Taxonomic identification of the fungal/Oomycete isolates from cultural methods was initially based on morphology, but we subsequently used DNA from each isolate amplified by polymerase chain reaction (PCR) with primer pairs ITS4/ITS5 (White et al. 1990) to verify our identification. To aid in the identification of Fusarium species, we sequenced a second marker region, the partial EF- $1 \alpha$ gene using primer pairs EF1/ EF2 (O'Donnell et al. 1998). We identified four main pathogen groups associated with diseased RCR plant tissue from sequencing of both the DNA from the FTA $®$ Cards and/or plant tissue extracts. To verify these species complexes, we utilized isolate-specific markers for these pathogens using the following specific primer pairs (Table S-4): FM66/58 COX II for Pythium species (Martin 2000); ITSFu F/ITSFu R for Fusarium species (Abd-Elsalam et al. 2003); RS4 primers for/RS4 primers for Rhizoctonia solani (Guillemaut et al. 2003) and MpkF1/MpkR1 primers for Macrophomina phaseolina (Babu et al. 2007). Isolates of Macrophomina phaseolina, Pythium ultimum, Rhizoctonia solani strain AG- 4, and F. oxysporum collected from field grown dry beans from Scottsbluff, NE, USA, were used throughout our tests for PCR quality control. For each amplification, $25 \mu \mathrm{l}$ of PCR reaction mixture was prepared by adding $1 \mu \mathrm{l}$ of genomic DNA to $24 \mu \mathrm{l}$ of a master mix/tube containing $9.5 \mu \mathrm{l}$ PCR grade sterile $\mathrm{ddH}_{2} \mathrm{O}, 12.5 \mu \mathrm{l}$ Econotaq ${ }^{\circledR}$ PLUS GREEN $2 \times$ Master mix (Lucigen, Madison, WI, USA), and using $1 \mu \mathrm{l}$ of $0.2 \mathrm{mM} / \mu \mathrm{l}$ of each forward and reverse primers. Reactions were performed in a PTC-100 thermal cycler (Bio-Rad Laboratories, Hercules, CA, USA). Amplification fragments were separated by electrophoresis in a 1.5\% Ultra-Pure ${ }^{\circledR}$ and Quick Dissolve agarose (Invitrogen, Carlsbad, CA, USA) in TBE buffer and stained with ethidium bromide for visualization under a UV light using a ChemiDoc EQ System with the software package Quantity One (Bio-Rad Laboratories, CA, USA). Amplified fragments for Sanger sequencing were purified with Ultra-Clean PCR Clean-Up Kit (Cat. No. 12500-50 MO BIO Laboratories, Inc., Carlsbad, CA, USA), and sequenced on an ABI 3730XL Sanger Sequencer by ACGT, Inc. (Wheeling, IL, USA).

DNA extracted from the FTA $®$ Cards of field infected RCR plants was isolated with the goal of using both sequence identification methods and phylogenetic analysis of the fungal/ Oomycete composition in the plant lesions (Herr et al. 2015; Hibbett et al. 2016). Sequencing was conducted 
at Molecular Research LP (www.mrdnalab.com-Shallowater, TX, USA) on an Illumina MiSeq (Ilumina, Inc., San Diego, CA, USA) using PCR primers Euk SSU euk7F/euk570R amplifying the 18S rRNA gene V4 variable region. Sequence data was processed using a taxonomic analysis pipeline (Chiodini et al. 2016) where the raw data set was demultiplexed and barcodes and primers were trimmed from the sequences. The sequence data was subsequently processed by removing sequences $<200$ $\mathrm{bp}$, as well as reads with homopolymer runs exceeding $10 \mathrm{bp}$ and ambiguous base calls. Sequencing chimeras were detected and removed, and operational taxonomic units (OTUs) were generated by centroid clustering at 3\% divergence (using vsearch at $97 \%$ similarity; Rognes et al. 2016) followed by removal of true singleton sequences for downstream analysis (Chiodini et al. 2016). Final OTUs were identified using BLASTn against the curated GreenGenes (DeSantis et al. 2006, McDonald et al. 2012), RDPII (Cole et al. 2005), and Silva (Quast et al. 2012) databases, respectively.

\section{Pathogenicity assay}

Pathogenicity assays were conducted using 333 fungal and/or Oomycete isolates recovered from the RCR diseased plant tissue. Two-weekold susceptible PINTO 114 bean seedlings, grown in the greenhouse using $6 \times 4 \mathrm{~cm}$ plastic pots containing steam pasteurized sterilized soil mix, were inoculated using a modified straw test method (Mukuma et al. 2020). Each inoculation was replicated five times and plants were kept in a mist chamber set for humidity $\geq 80 \%$ and temperatures approximating $23^{\circ} \mathrm{C}$. Control plants were inoculated with clean PDA plugs containing no visible organismal growth. After $48 \mathrm{~h}$, all plants were moved to greenhouse benches and arranged in a complete randomized block design. Lesion length for each plant was measured and recorded $48 \mathrm{~h}$ after removal from the mist chamber (Fig. 2e). Lesion data were analyzed using Statistical Analysis System (SAS) v 9.2 (SAS Institute, Inc. Cary, NY, USA). Mean comparisons were made using Fisher's protected least significance difference at $P=0.05$. To fulfill Koch's postulates, the fungi were re-isolated from the infected petiole, grown on WA, and subsequently transferred to PDA (as previously described) to re-validate cultural and morphological features. 


\section{PCR fingerprinting of Fusarium oxysporum with microsatellite markers}

The genetic diversity of $F$. oxysporum isolates recovered from RCR diseased plant tissue was determined using PCR fingerprinting analysis with four types of microsatellites. Previously utilized for Fusarium taxa (Kang et al. 2002), the universal rice primer (URP) (5'CCCAGCAACTGATCGCACAC3') was used to amplify Fusarium isolates and microsatellites with the repeated motifs (GTG) 5 (Lieckfeldt et al. 1993; Brasileiro et al. 2004), (ACG)5, and (AGG)5 (Bahkali et al. 2012). Two primers, the (ACG)s and (AGG)s motifs, were chosen from a set of 3 URPs, because they yielded the most consistent and unambiguous fragments and amplified most of the Fusarium isolates we obtained. DNA samples from 93 F. oxysporum isolates ( 72 from Gurue and 21 from Chokwe) were amplified with the primers following published protocols (Table S-4). The PCR amplification reactions were prepared for each of the primers and band visualization was done as previously described. Band size and number in the gel were determined in the Band Analysis tools of ImageLab software, version 4.1 (Bio-Rad, Carlsbad, CA, USA). After being scored, the resulting data set was analyzed using the nei.dist $($ function within Poppr (Nei 1973, Kamvar et al. 2014) using R (R Core Team 2018).

Clear and unambiguous bands, amplified by the microsatellite markers, were selected and scored for presence (1) or absence (0) of the corresponding band, which ranged from 300 to $1000 \mathrm{bp}$. A nonclone-corrected binary data matrix was computed with Genalex v. 6.502 (Peakall and Smouse 2006) and SAS v. 9.2 (SAS Institute, Inc. Cary, NY, USA) utilizing morphological characteristics from the original isolate used in the inoculation assay.

\section{Data visualization and analysis}

Sequence chromatograms of ITS rDNA and the partial EF- $1 \alpha$ genes were visualized with Chromat version 2.6.4 (Technelysium Pty., Australia) and after inspection, the resulting FASTA files were exported for further analysis. To infer the identification of the isolates at putative species level, the ITS rDNA sequences were identified using the NCBI BLAST web interface (https://blast.ncbi.nlm.nih.gov/Blast. cgi) against the NCBI GenBank nt database. Identification of the partial EF-1 $\alpha$ gene to the closest 
matching Fusarium species was conducted by BLAST analysis against the Fusarium EF blast cyber-Infrastructure website (http://fusariumdb.org/ index.php) available through the Pennsylvania State University, University Park, PA, USA (Park, et al. 2010). For phylogenetic analysis and placement, the FASTA files of the partial EF-1 $\alpha$ gene sequences were subjected to multiple sequence alignment (MSA) using MUSCLE (Edgar 2004) and the resulting alignment was used for the phylogenetic tree construction. Phylogenic analysis was conducted using Bayesian inference with the BEAST pipeline (Drummond and Rambaut 2007). Sequences of F. oxysporum from various $F$. oxysporum forma specialis phaseoli accessions from NCBI GenBank showing 99 to $95 \%$ synteny were selected as outgroups and to add resolution beyond those sequences collected for this study. The resultant tree was visualized using iTOL (Interactive Tree of Life-http://itol.embl.de/; Letunic and Bork 2016).

The overall abundance of taxa among the samples from the different sampling locations and years were estimated from the identification of OTUs from the Illumina MiSeq sequencing. Heat maps were constructed in R (R Core Team 2018) using the ggplot2 (Wickham 2016) and RColorBrewer packages (Neuwirth, 2014), based on the percent of relative abundance obtained from Illumina MiSeq 18S sequencing for FTA ${ }^{\circledR}$ Cards and RCR diseased plant tissue. Sequences with reads depth less than 10, which we considered putative sequencing artifacts, were removed from further analysis. The overall sample diversity, which was measured as Shannon (Shannon and Wiener, 1963) and Simpson (Simpson 1949) indices, was calculated with the PAST (PAleontological STastics) v 3.12 program (Hammer et al. 2001). Venn diagrams, constructed with Venny 2.1 (http://bioinfogp.cnb.csic.es/ tools/venny/), were drawn to display similarities (shared reads) and distinctiveness (unique reads) among F. oxysporum for the Gurue and Chokwe locations based on Illumina MiSeq $18 \mathrm{~S}$ and EF-1 $\alpha$ sequence data. Sequencing data from the MiSeq run was used to validate the culture-based and PCR amplified methods for detecting the four main RCR pathogens we identified in this field study. This analysis was conducted by Spearman's rank and rho correlation which was also calculated within the PAST program.

The frequency of the four main fungal/Oomycete genera and species (Fusarium spp., Macrophomina phaseolina, Rhizoctonia solani and Pythium spp.) was generated by PCR amplification with specific primers. 
A binary matrix was constructed with the color-coded data set for each as presence (1) and absence (0) of the expected fragment. Tables were constructed for each location per year.

\section{Results}

\section{Cultural and morphological characterization of isolates obtained from RCE tissue}

We obtained 333 fungal and Oomycete isolates in culture, as examined by macro- and microscopic characteristics, from $79 \%$ of RCR tissue samples collected in Chokwe and Gurue in 2014 and 2015. Most of the isolates were initially assigned at the genus or species level, based on their characteristic mycelial and spore features, although some isolates did not sporulate or had no diagnostic cultural characteristics. Isolates of Alternaria spp., Fusarium spp., Pythium spp., M. phaseolina, and R. solani were significantly more abundant than other taxa in the samples. Among the identified isolates, Pythium spp. had the fastest growth rate and $M$. phaseolina the slowest. The morphology and size of both phialides and spores, based on growth characters from CLA plates, were used to tentatively identify the Fusarium species into 3 morphotypes and/or species complexes: F. solani, F. oxysporum, and F. equiseti (Fig. 3), prior to DNA sequencing analysis.

\section{Identification of cultured isolates}

We identified the taxa of cultured isolates of fungi and Oomycetes through DNA sequencing and subsequently compared the recovery of the isolates from Whatman FTA ${ }^{\circledR}$ Cards and RCR tissue. Nucleotide sequence data were identified to closest match using BLAST queries with a cut-off value $>98 \%$ match and a resultant 42 distinct fungal taxa were identified (Table S-5). Fusarium oxysporum was by far the most common genus and species (Figs. 4, 5 and 6). In comparison, the most frequently isolated genus and species in both locations were F. oxysporum (34\%) F. equiseti (13\%), F. solani (10\%), A. alternata (9\%), M. phaseolina (4\%), and $R$. solani (2\%) (Fig. 4). 


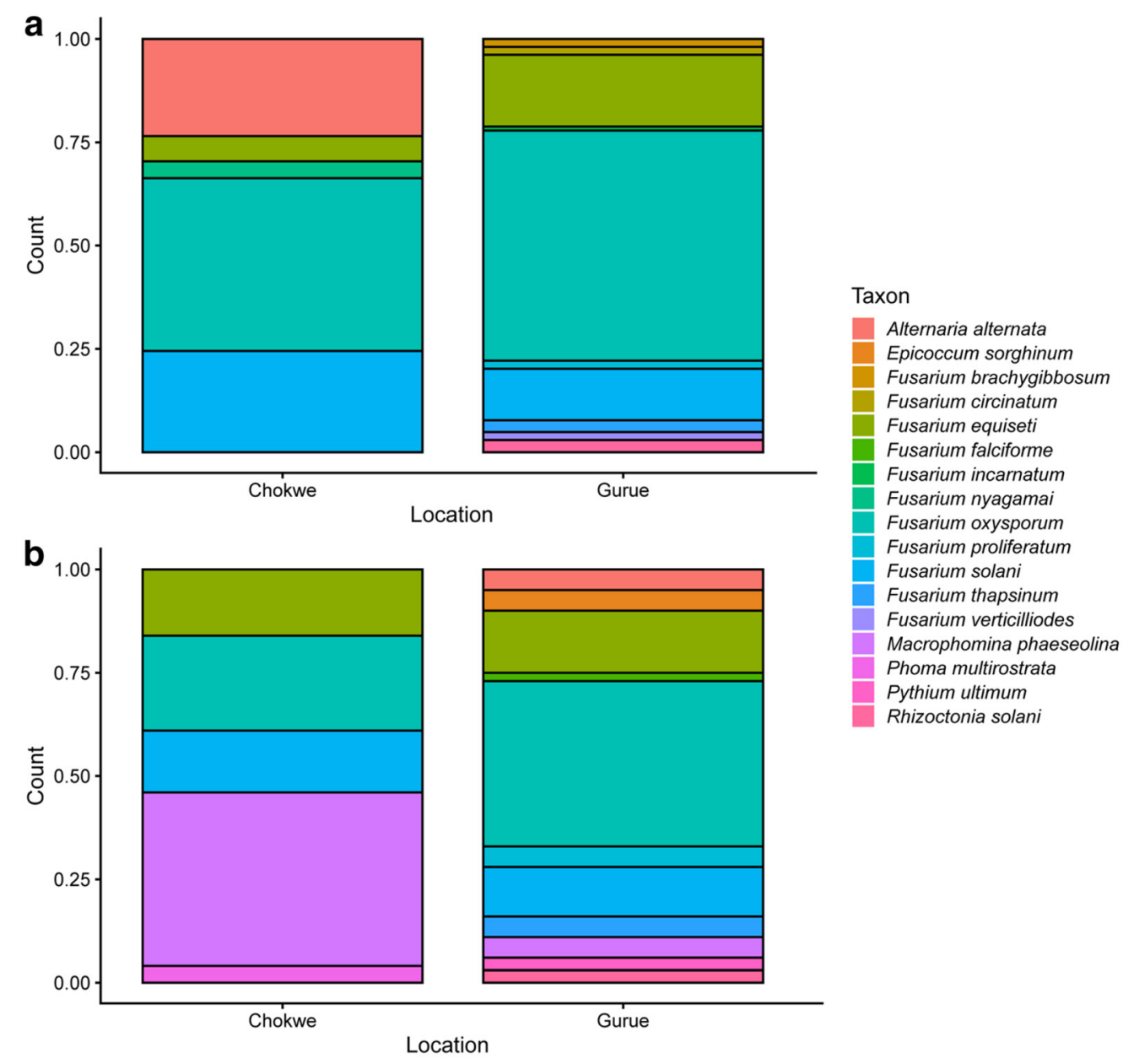

Fig. 4 Relative abundance of the 17 most prevalent identified pathogenic fungi and Oomycetes isolated from isolated RCR bean tissue through 18S rDNA Illumina sequencing for years (a) 2014 and (b) 2015, by location of pooled Chokwe and pooled Gurue growing regions.

\section{Pathogenicity assay}

The 333 isolates recovered from RCR plant tissues were tested for pathogenicity and 204 were identified as inducing pathogenic-like responses in bean assays (Table S-5) in the greenhouse. We used the criteria of water-soaking followed by necrosis or wilting of the stem of 14-dayold Pinto 114 bean plants observed 3 days after inoculation as exhibiting traits of pathogen damage. Mean lesions ranged from 0.4 to $8 \mathrm{~cm}$ in length. The most common isolate recovered from our pathogenicity tests was Fusarium oxysporum, followed by F. equiseti and F. solani 
Fig. 5 Heat map of normalized relative abundance of the top 92 fungal operational taxonomic units associated to RCRsymptomatic beans based on 18S rDNA region Illumina sequencing from the pooled Chokwe growing regions in 2014 and 2015.

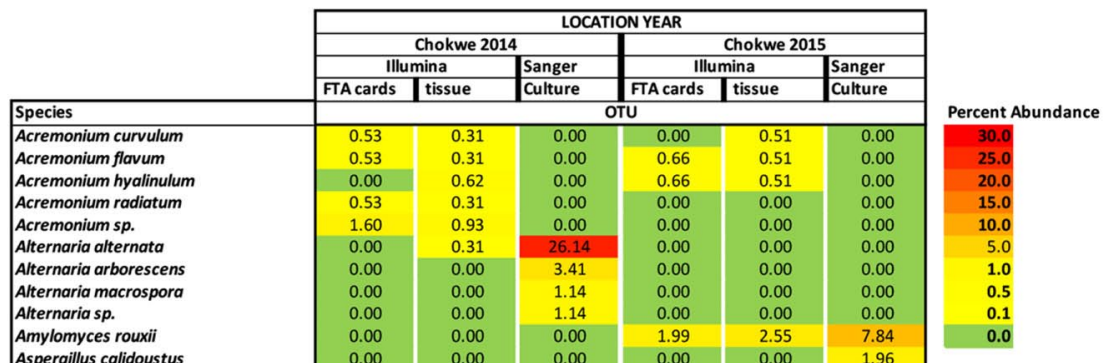


Fig. 6 Heat map of normalized relative abundance of the top 107 fungal operational taxonomic units associated to RCRsymptomatic beans based on 18S rDNA region Illumina sequencing from the pooled Gurue growing regions in 2014 and 2015.

\begin{tabular}{|c|c|}
\hline & \\
\hline & \\
\hline & $\begin{array}{l}\text { Illuu } \\
\text { Fitacrds }\end{array}$ \\
\hline Species & \\
\hline Acremonium blochii & \\
\hline Acremonium curvulum & 0.54 \\
\hline Acremonium flavum & 0.54 \\
\hline $\begin{array}{l}\text { Acremonium hyalinulum } \\
\text { Acremononum nirosclerotium }\end{array}$ & 0.000 \\
\hline $\begin{array}{l}\text { Acremonium ingrosclerotium } \\
\text { Acremonium sp. }\end{array}$ & 0.00 \\
\hline Acremonium sclerotigenum & 0.00 \\
\hline Alternaria alternota & 0.00 \\
\hline 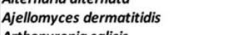 & 0.00 \\
\hline Arthopyrenia salicis & 0.00 \\
\hline $\begin{array}{l}\text { Aspergillus fumigatus } \\
\text { Assergills nier }\end{array}$ & 0.00 \\
\hline $\begin{array}{l}\text { Aspergiglus nnger } \\
\text { Aspergillus penicillioides }\end{array}$ & 0.54 \\
\hline $\begin{array}{l}\text { Aspergillus terreus } \\
\text { Assper }\end{array}$ & 0.54 \\
\hline Athelia rolssii & 4.32 \\
\hline Bullera penniseticola & 0.00 \\
\hline Bullera sp. & \\
\hline $\begin{array}{l}\text { Bulleromyces albus } \\
\text { Blllimyecs ouritsporus }\end{array}$ & 0.54 \\
\hline $\begin{array}{l}\text { Bullimycess unrtrporus } \\
\text { Cotenaria onguillulae }\end{array}$ & $\begin{array}{l}1.08 \\
0.00\end{array}$ \\
\hline 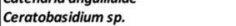 & 0.00 \\
\hline Cladorrhinum samala & 0.00 \\
\hline Cladosporium cladosporioides & 4.86 \\
\hline Cochliobolus sp. & 0.54 \\
\hline $\begin{array}{l}\text { Cochlilobolus sativus strain } \\
\text { Colletorticum sp. }\end{array}$ & 0.00 \\
\hline $\begin{array}{l}\text { Colletotrichum sp. } \\
\text { Coniochaeta veluting }\end{array}$ & $\begin{array}{l}0.54 \\
1.08\end{array}$ \\
\hline 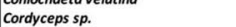 & 0.00 \\
\hline Cryptococcus flavus & 0.00 \\
\hline Cystoffiobasidium ferigula & 0.00 \\
\hline Entoloma strictiu & 0.00 \\
\hline $\begin{array}{l}\text { Epicoccum sorghinum } \\
\text { Eurotium repens }\end{array}$ & 0.00 \\
\hline $\begin{array}{l}\text { Eurotium repens } \\
\text { Fusarium brachyoibbosum }\end{array}$ & 0.00 \\
\hline Fusarium circinatum & 0.00 \\
\hline Fuscrium equiseti & 0.00 \\
\hline Fuscrium falciforme & 0.00 \\
\hline Fusarium incarnotum & 0.00 \\
\hline $\begin{array}{l}\text { Fuscrium oxysporoum } \\
\text { Fusararium proliferatum }\end{array}$ & 年3.18 \\
\hline 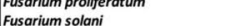 & 8.05 \\
\hline $\begin{array}{l}\text { Fuscrium sp. } \\
\text { fus. }\end{array}$ & 1.62 \\
\hline Fuscrium thpopsinum & 0.00 \\
\hline Fusarium verticillioides & 0.00 \\
\hline Geomyces sp. & 0.00 \\
\hline $\begin{array}{l}\text { Geosmithia putteriliti } \\
\text { Glilocldodium s. }\end{array}$ & $\begin{array}{l}4.86 \\
.54\end{array}$ \\
\hline 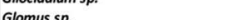 & 054 \\
\hline Graphiola phoenicls & 0.00 \\
\hline Graphium penicillioides & 0.00 \\
\hline Grophium putredin's & 1.08 \\
\hline Helicogloea variabilis & 0.00 \\
\hline 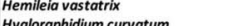 & 年.16 00 \\
\hline $\begin{array}{l}\text { Hyalorophidifum curvatum } \\
\text { Hypocrea jecorina }\end{array}$ & 0 \\
\hline 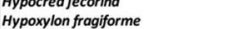 & 0.00 \\
\hline $\begin{array}{l}\text { Inocephalus sp. } \\
\text { Inte }\end{array}$ & 0.00 \\
\hline Leptosphaeria maculans & 2.16 \\
\hline 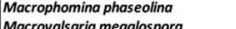 & 0.00 \\
\hline $\begin{array}{l}\text { Macrovalsaria megalospora } \\
\text { Metagne }\end{array}$ & 1.08 $\quad l \quad l$ \\
\hline $\begin{array}{l}\text { Melanops stulasnei } \\
\text { Melacososporat tiffinit }\end{array}$ & 0.00 \\
\hline $\begin{array}{l}\text { anosporar tijo } \\
\text { tierella alpina }\end{array}$ & 0.00 \\
\hline Mortierella sp. & 0.00 \\
\hline Mucor circinelloides f. circinello & 0.00 \\
\hline Myrothecium leucotrichum & 0.00 \\
\hline $\begin{array}{l}\text { Neocosmospora vasi } \\
\text { Neurosporacrssa }\end{array}$ & 0.54 \\
\hline $\begin{array}{l}\text { Neurossoprac cras } \\
\text { Niessliaexils }\end{array}$ & 0.5 \\
\hline $\begin{array}{l}\text { sillillium pilis } \\
\text { inophilum }\end{array}$ & 0.0 \\
\hline Penicillium purpurogenum & 0.54 \\
\hline Penicillium siamense & 0.54 \\
\hline Petromyces & \\
\hline arum & 0.54 \\
\hline $\begin{array}{l}\text { Phom } \\
\text { Phy }\end{array}$ & . \\
\hline , concovum & 0.00 \\
\hline & 0.00 \\
\hline Pleospora herbarum & 3.78 \\
\hline & \\
\hline $\begin{array}{l}\text { Pseudohai } \\
\text { Pesedroy }\end{array}$ & 2.70 \\
\hline 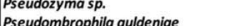 & 0.00 \\
\hline 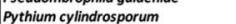 & 1.08 \\
\hline & 2.1 \\
\hline & 1.08 \\
\hline$P y t$ & \\
\hline & $\begin{array}{l}2.16 \\
2,70\end{array}$ \\
\hline & 2.7 \\
\hline$R h c$ & 0.00 \\
\hline & 0.5 \\
\hline Rhodotorula pinicola & 0.00 \\
\hline & \\
\hline & 1.08 108 \\
\hline & 0.00 \\
\hline $\begin{array}{l}\text { Septoria epambros } \\
\text { S }\end{array}$ & 0.05 \\
\hline setosphoeria mono & 0.54 \\
\hline Taphrina deformans & 0.00 \\
\hline & 0.00 \\
\hline & 0.00 \\
\hline & 0.54 \\
\hline & 0.00 \\
\hline tirunneum & 0.00 \\
\hline & 0.00 \\
\hline Verticillium dahhioe & \\
\hline
\end{tabular}


from both locations of farm fields, with the exception of samples from Chokwe 2015, where Macrophomina phaseolina was the most virulent isolate we encountered.

\section{Detection of four primary pathogenic isolates associated with RCR}

Microsatellite amplicon sequences from the infected samples and positive controls were consistent with the expected fragment sizes for Fusarium spp., Pythium spp., Rhizoctonia solani, and Macrophomina phaseolina. With the primers we utilized, the presence or absence of each genus and/or species per sample was detected (Fig. 7). The frequency of detection varied with both location and year; however, Fusarium spp. were detected in highest frequencies and in RCR tissue more than in Whatman FTA® Cards (Fig. 7).

When Illumina sequencing was used for DNA analysis from both FTA® Cards and RCR tissue, not surprisingly, we identified a greater depth of species of fungi/Oomycetes than from the culture-based method (Fig. $7)$. By location and year, overall, $F$. oxysporum was the most frequently identified isolate in both FTA® Cards and RCR tissue, followed by F. solani and other Fusarium species, as well as Rhizoctonia solani (Figs. 4, 5, and 7). Other fungal/Oomycete species that have been associated with RCR symptoms such as Pythium ultimum were less frequently observed. We found it notable that a fungal taxon identified in culture from RCR infected legumes, $M$. phaseolina, was not detected by Illumina amplicon sequencing in either location or year with the Whatman FTA® Cards. Finally, there was a significant correlation between information obtained by FTA $®$ Cards and RCR tissue values based on the Spearman correlation coefficient for Gurue (0.759 and 9.86516, $P<0.001$ ) and Chokwe $(0.70288$ and $0.865, P<0.001)$ for 2014 and 2015 , respectively.

\section{Phylogenetic affinities of Fusarium oxysporum and genetic variation for Fusarium oxysporum assessed with microsatellite primers}

To detect the four major pathogen genera and species (Fusarium spp., R. solani, P. ultimum, M. phaseolina), we employed Illumina amplicon sequencing, PCR-based microsatellites, and culture-based methods. The Illumina amplicon sequencing identified the most fungi and Oomycetes from FTA® Cards. However, PCR-based methods from RCR tissue were best at detecting M. phaseolina (Fig. 7). Every method that we employed 


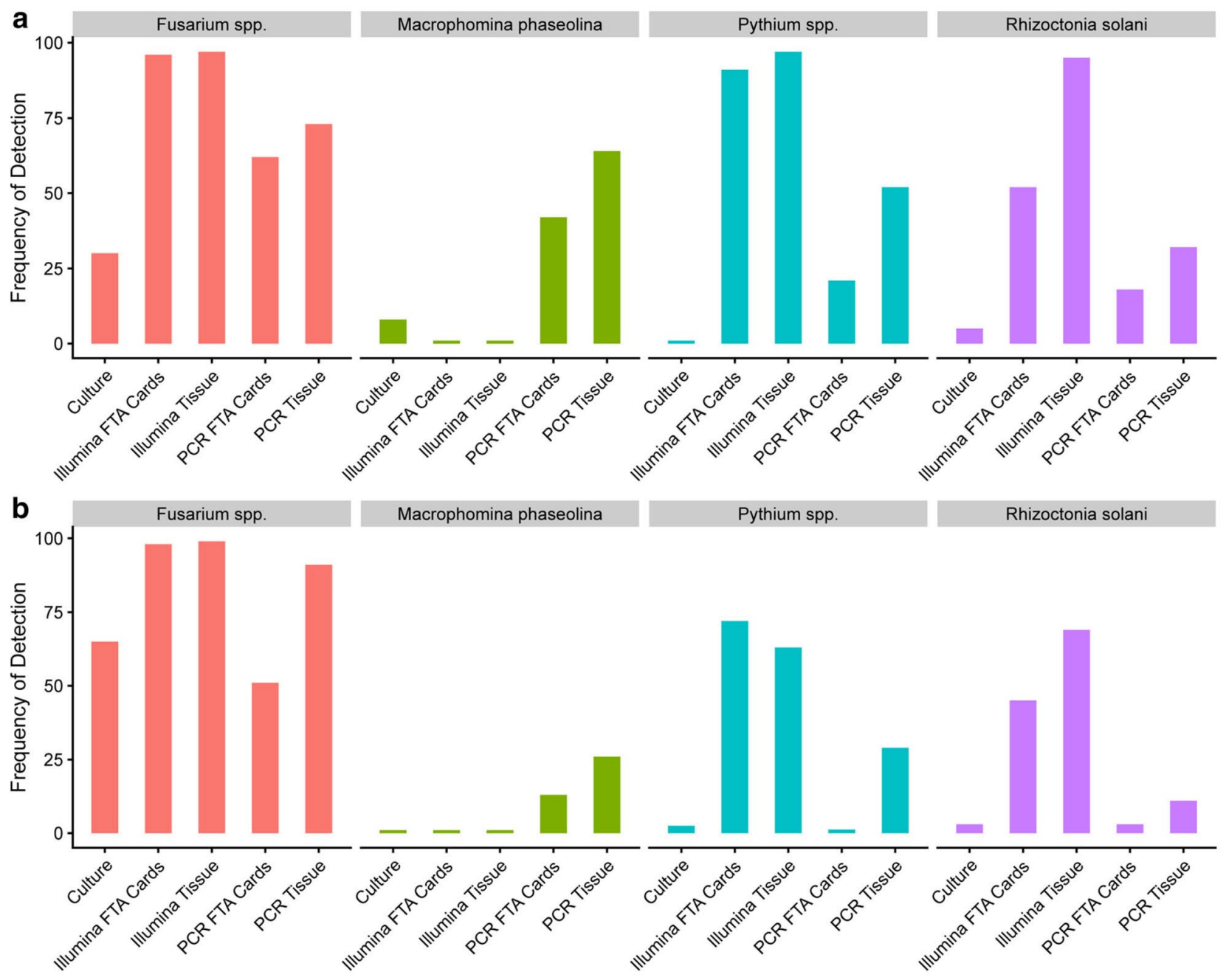

Fig. 7 Detection frequency across the years of 2014 and 2015 for the four main pathogens we identified (all Fusarium species, Macrophonima phaseolina, all Pythium species, and Rhizoctonia solani) associated with RCR of beans from sampling sites of (a) Chokwe and (b) Gurue in Mozambique. The methods used for detection in this study were (1) culture-based, (2) Illumina MiSeq FTA Card, (3) Illumina MiSeq tissue sample, (4) primer-specific polymerase chain reaction amplification FTA Card, and (5) primer-specific polymerase chain reaction amplification of tissue sample.

identified Fusarium spp. as the most abundant pathogen group in RCR tissues. Other Pythium species, as well as R. solani, were also detected by amplicon sequencing at higher frequencies than PCR-based or culture-based methods. The frequency of detection of the four most abundant pathogens was higher in the direct assay of RCR diseased plant tissue than in FTA ${ }^{\circledR}$ Cards for samples from both farm field locations in 

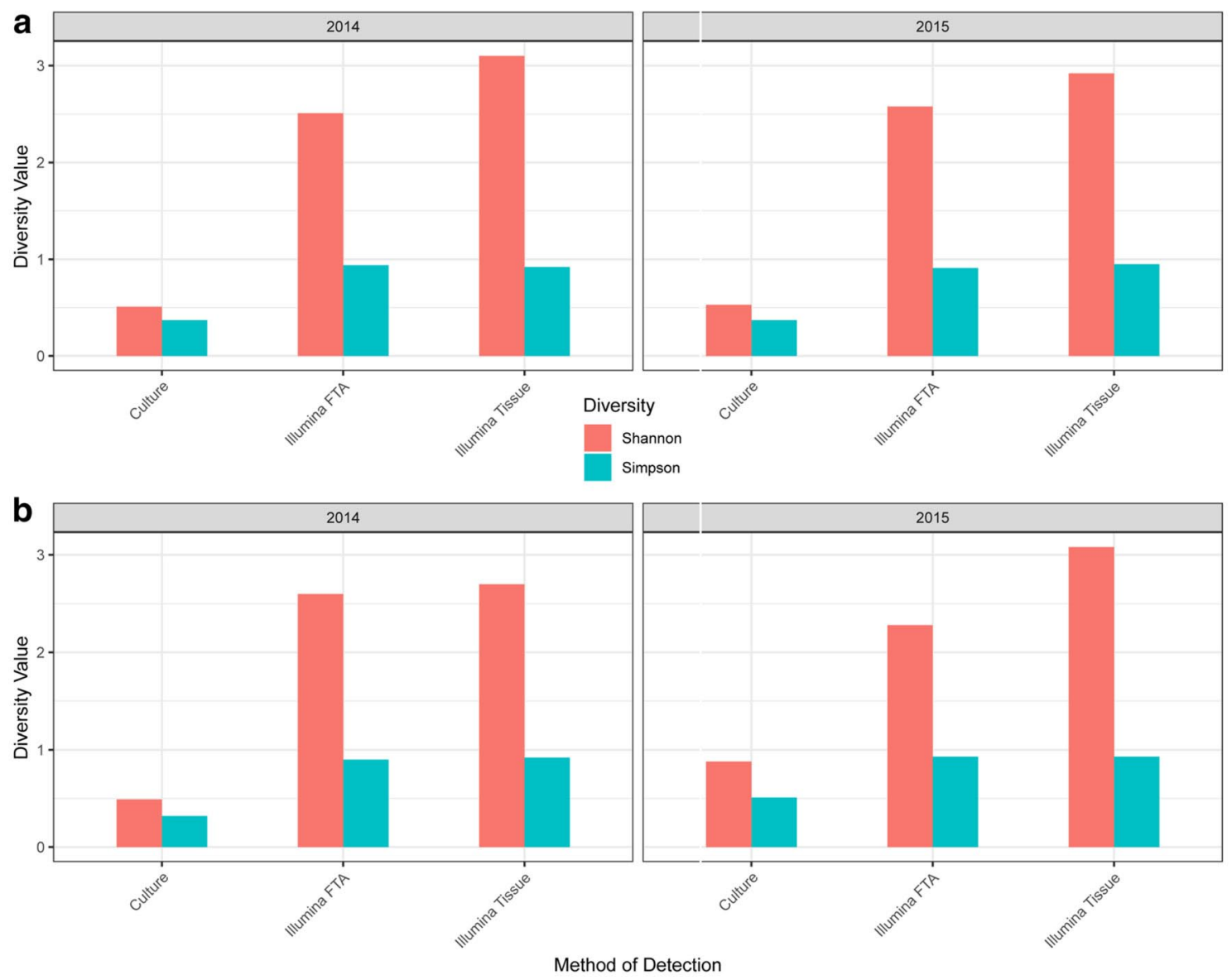

Fig. 8 Diversity metrics (Simpson and Shannon indices) for the (a) pooled Chokwe growing region RCR bean samples and the (b) pooled Gurue growing region RCR bean samples in 2014 and 2015 using the different diagnostic analysis methods we employed: (1) culture-based methods, (2) Illumina sequencing of FTA Card DNA extractions, and (3) Illumina sequencing of directly sampled RCR tissue DNA extractions directly sampled tissue samples.

Mozambique. The culture-based methods had the lowest detection frequency for species of Pythium, R. solani, and M. phaseolina, but they isolated and identified numerous species of Fusarium. The two locations sampled showed differences in community diversity (based on the value of $\mathrm{H}^{\prime}>2.5$ ) which revealed the presence of diverse array of isolates associated with RCR disease, whereas Simpson values close to 1 show the predominance of one species or group, which was the case for Fusarium, where these taxa were found in the same plant niche for most locations and year tested (Fig. 8). The exception was for the Chokwe location in 2015, where M. phaseolina was the predominant fungal species 


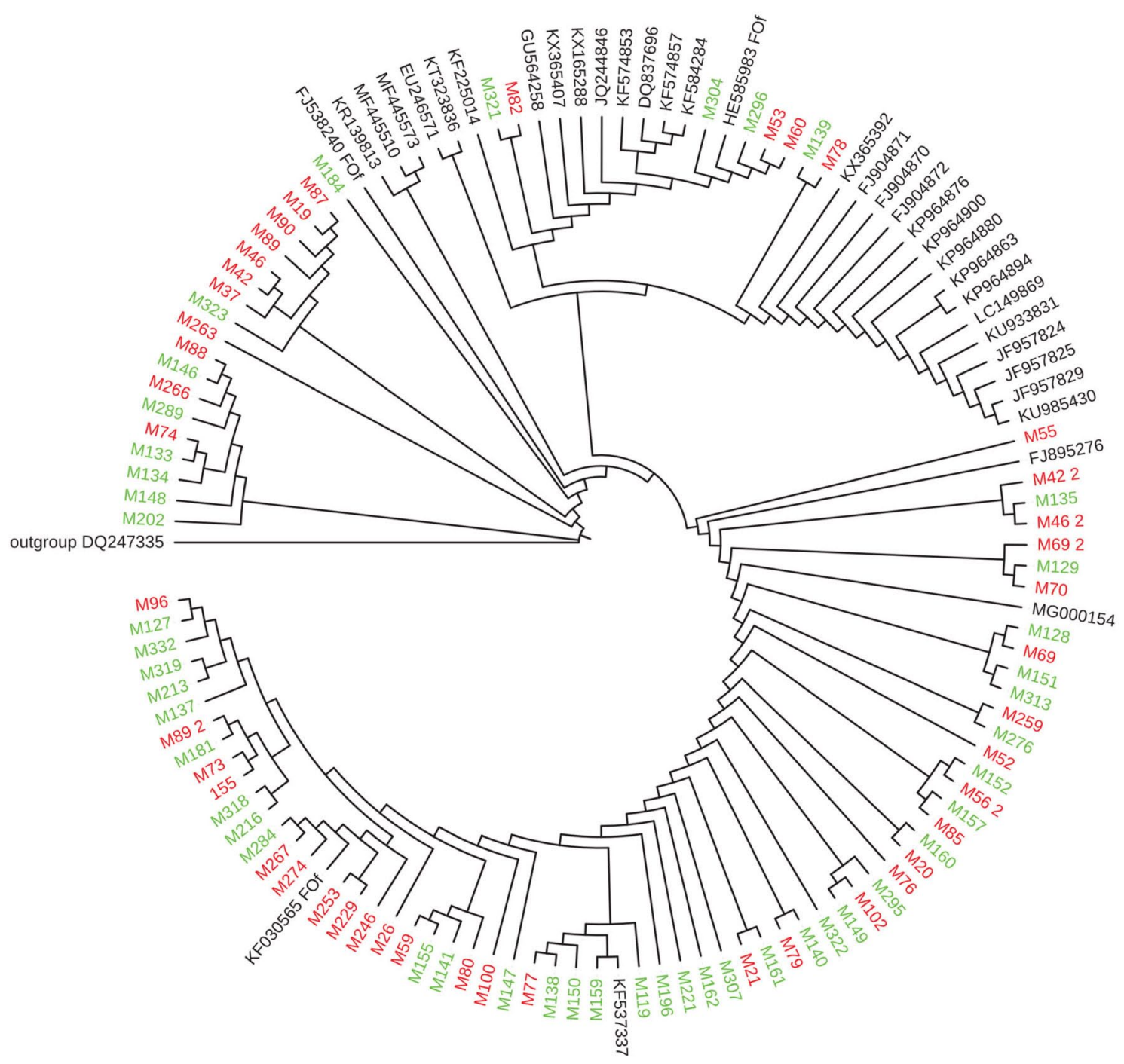

Fig. 9 Bayesian likelihood phylogenetic tree derived from partial EF-alpha gene region sequences of Fusarium oxysporum cultured isolates from Mozambique. Leaf names in green were isolated in from RCR-symptomatic samples from the Gurue region and leaf names in red were isolated from RCR-symptomatic samples from the Chokwe region. Leaf names in black represent 36 Fusarium oxysporum partial EF-alpha gene accessions from database of NCBI GenBank.

in culture. Values of Shannon and Simpson diversity indices were similar for both locations and years where F. oxysporum had the highest percentage of relative abundance. Of the most predominant species, $F$. oxysporum, was further examined for better taxonomic resolution by sequencing the partial EF-alpha gene and the sequences were used to construct a phylogenetic tree (Fig. 9). The phylogenetic tree revealed at least 
seven well-defined clusters within F. oxysporum species complex indicating intraspecific variability of the partial EF-1 gene. Additionally, most of the isolate sequences were separated from those of published $F$ oxysporum accessions from the NCBI GenBank database indicating the new isolates from Mozambique are not found in databases. There was no evidence that geographical origins of the isolates influenced the clustering pattern because sequences from both locations were found in species complex clusters. Phylogenetically informative nucleotide positions in the 18S rRNA sequences (generated by the Illumina amplicon sequencing) were used to compare common or shared OTUs in different combinations between the Chokwe and Gurue locations for both years and presented in Venn diagrams (Fig. 10). These common, or shared, amplicon counts are displayed in the overlapping panels and unique OTUs in the non-overlapping areas.

Fig. 10 Euler diagrams depicting shared (intersecting) and unique (not intersecting) operational taxonomic units of Fusarium oxysporum identified with Illumina MiSeq analysis of the 18S rDNA region sequences from RCR-symptomatic beans plants in (A) 2014 and (B) 2015 from the pooled samples of the Chokwe and Gurue growing regions in Mozambique.

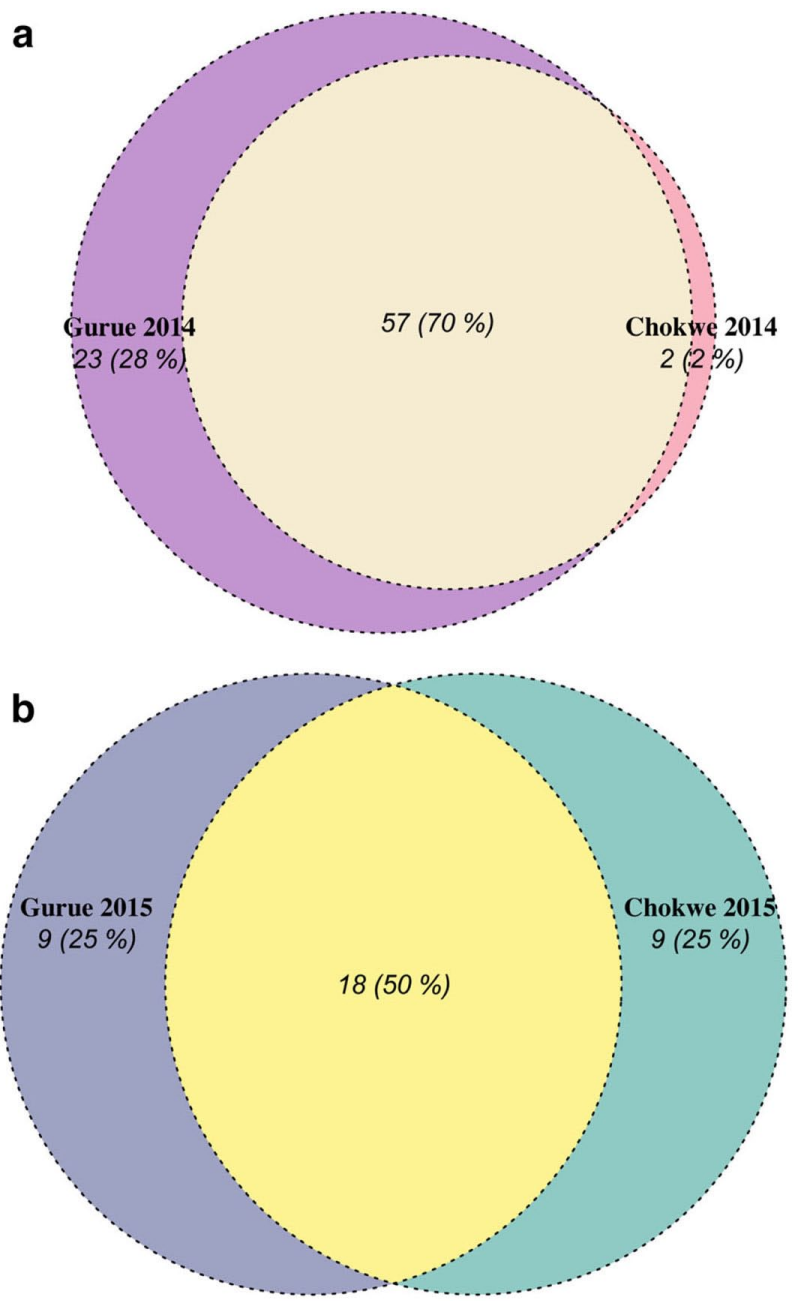


There were 91 isolates of $F$. oxysporum from Chokwe and Gurue characterized with single microsatellite primers (URP2R, (GTG)5, (ACG)5, and (AGG)5) which generated 16 reproducible fragments, as well as 27 scorable fragments. The fragments (or allele) sizes ranged from 100 to $>2000 \mathrm{bp}$, although for ease of interpretation we only scored those with the range of 200 to $1000 \mathrm{bp}$. Not all of the isolates amplified using all four primers with the same efficiency. We identified diversity indicators for the Chokwe and Gurue group of isolates utilizing the microsatellite primers URP2R, (GTG)5, (ACG)5, and (AGG)5 (Table S-1), and for example, the percentage of the polymorphisms was highest when we utilized the (AGG)5 primer set when compared to the rest of the primers. Nei's gene diversity (for heterozygosity estimates), unbiased Nei's gene diversity (a correction for small number of samples), and Shannon's Information Index (extent of genetic variation) (Table S-2) all displayed low values indicating a small genetic distance between the Chokwe and Gurue F. oxysporum isolate groups. Analysis of molecular variance revealed that the percentage of total variation within the locations was higher than the variation found between locations. In conclusion, we detected no structural population differences between F. oxysporum isolate groups for each location based on the number of isolates and primers tested (Table S-1).

\section{Discussion}

The identification of plant pathogens is an important first step to develop preventive management strategies and identify resistant dry edible bean cultivars to root and crown rot (RCR) diseases. In this study we employed three methods to identify the primary causal agent of RCR in dry edible beans in Mozambique: amplicon sequencing of the $18 \mathrm{~S}$ rRNA and EF1 marker regions, genus and species-specific microsatellite primer amplification paired with morphological identification of cultural material, and DNA sequencing of the ITS rDNA region of the cultured fungi and Oomycetes.

Amplicon sequencing methods revealed the presence of a greater diversity of fungal and Oomycete species than culture-based methods. In all of the methods we employed, species of Fusarium, mainly F. oxysporum, were the dominant fungal isolates detected either on DNA extracted 
from FTA $®$ Cards and RCR diseased plant tissue, or from isolates recovered through conventional culture methods. Other RCR disease- associated fungi, such as R. solani, Pythium spp., A. rolsfii, and M. phaseolina, were detected or isolated in cultured samples but were lower in abundance and typically inconsistent in their presence and absence. The exception to this was found in the samples from Chokwe in 2015 where we identified $M$. phaseolina from both the sequencing and culture methods. Other fungal species we detected by amplicon sequencing, widely distributed across the Ascomycota and Basidiomycota, are not known to be associated with RCR and could be considered plant endophytes. The role of these fungi as endophytes in healthy or diseased dry bean plant tissue is yet to be well established (Nair and Padmavathy 2014). Despite the high frequency of isolation of $M$. phaseolina from the 2015 samples collected in Chokwe, the symptoms observed in the collected root/crown samples did not match symptoms typically caused by $M$. phaseolina, which is known to infect the upper stem of more mature plants. We hypothesize that increased rainfall in the Chokwe region during our study resulted in this finding, as $M$. phaseolina has been reported to increase abundance in regions of the tropics and subtropics where crops might be exposed to water stress (Songa and Hillocks 1996). The high isolation frequency of $M$. phaseolina is likely due to climate variability in the 2014 and 2015 growing seasons, which were characterized by low rainfall from October to December of 2014, and the resulting drought in the southern region from January to March of 2015. Later, an El Niño phenomenon was reported in Mozambique in the 2015 growing season which a rainy season in the south of the country was followed by additional pronounced and excessive rain or floods in the northern region (C. Jochua, personal observations). Most of the symptomatic bean samples, which exhibited signs of wilting and necrosis of the stem even before the flowering stage, were associated with infection by species of Fusarium. These symptoms were typically associated with recurrent cyclical weather patterns in the country, such as flooding and drought, and have caused environmental conditions which favor the abundance of Fusarium species in all locations of Mozambique.

The results of this study are in agreement with previous work $\mathrm{Cu}-$ kuma et al. 2020) that found F. oxysporum was the predominant pathogen associated with RCR of bean in Zambia. However, Rusuku et al. (1997) also studied soil-borne pathogens causing the RCR disease from 
culture isolation and found species of Pythium to be the most frequently isolated pathogens, over F. oxysporum, M. phaseolina, and $R$. solani in the RCR complex in Rwanda. To complement the methods used in the previous studies conducted in Zambia and Rwanda, we implemented both amplicon sequencing and microsatellite-based methods as they reveal a finer scale genetic profile of pathogens rather than phenotypic profiles obtained via only using cultural methods (Hilton et al. 2016; Mukuma et al. 2020).

In spite of the limitations of not being able to culture all possible fungal isolates, the fungi that we did isolate could be directly tested for pathogenicity to screen dry bean germplasm for disease resistance. Collectively, we identified 333 fungi and/or Oomycetes isolates from Chokwe and Gurue regions in the 2014 and 2015 growing seasons and tested these for pathogenicity against a diversity panel of beans. At least $60 \%$ of the isolates were pathogenic to bean, and species of Fusarium, primarily F. oxysporum, collected from all locations and years produced the longest mean lesion lengths in our pathogenicity assays. Based on the isolation frequency from the field collections and overall pathogenicity observed across the bean diversity panel, we conclude that F. oxysporum plays the most predominant role in the bean RCR complex in Mozambique.

More than one pathogen causing RCR of bean was additionally reported by Rusuku et al. (1997) and Mukuma et al. (2020), suggesting a complex of pathogens such as Pythium spp., R. solani, M. phaseolina, F. oxysporum f. sp. phaseoli, and A. rolfsii may be interacting to cause bean RCR. The hypothesis that more than one pathogen causes RCR on beans may have implications in the identification and subsequent breeding in response to broad pathogen-specific RCR disease resistance (Abawi and Pastor-Corrales 1990; Wortmann et al. 1998; Chaudhary et al. 2006; Clare et al. 2010).

With regard to the Fusarium species we identified, F. oxysporum was the most frequently isolated in our study and identified among the most pathogenic fungi and/or Oomycetes isolated within Mozambique. These results support other studies conducted in Latin America, Spain, and the USA, where F. oxysporum has caused RCR outbreaks (Pastor-Corrales and Abawi, 1987; Alves-Santos et al. 2002). In addition, F. oxysporum has also been identified as a major pathogen in Central Africa where serious losses on improved climbing bean varieties were reported 
(Buruchara and Camacho 2000). This study found that pathogenic isolates of Fusarium, with F. oxysporum being most notable, were coexisting with other individual Fusarium taxa that were not observed to be pathogenic within the same plant. The finding that some of the Fusarium species were pathogenic and others were not detrimental to a plant host may be explained by their ubiquitous nature in habitats such as soil, water, and as plant endophytes (Lofgren et al. 2018). Therefore, it is not unusual to have pathogenic and non-pathogenic isolates together in a healthy plant, which contribute to the early development and severity of disease when conditions are unfavorable for bean growth (Leslie and Summerell 2006; Estevez de Jensen et al. 2004; Harveson et al. 2005). It is important to note that Fusarium taxa that are typically recognized as opportunistic pathogens and will infect plants under the induction of stressful conditions such as those common in changing climate scenarios (Valverde-Bogantes et al. 2019). We note that, along with F. oxysporum, a large portion of the Fusarium species complexes identified here were identified as F. solani and F. equiseti and that we did not investigate in more detail here. We expect these species complexes will be the focus of additional studies inspecting morphotypes and genetic diversity of all RCR bean-associated Fusarium taxa.

Based on the amplicon sequencing portion of our study, we identified a diverse community of fungal and Oomycete taxa associated with RCR diseases of bean in two geographically distant regions in Mozambique. A relatively high fungal diversity in different environments has been reported in other studies of the dry bean microbiomes in tropical regions (Pastor-Corrales and Abawi 1987; Alves-Santos et al 2002, Buruchara and Camacho 2000), supporting high-throughput sequencing methods which provide better estimates of the overall fungal diversity of a sample when compared to other identification methods. High-throughput sequencing methods, such as the amplicon sequencing methods we employed in this study, are sensitive methods to identify pathogens associated with RCR when compared to culture-based techniques using morphological approaches that are better suited to only detect individual taxa or those that are easier to culture. Culture-based assessments of diversity can be problematic as some particular species can be isolated with ease in a laboratory setting as they rapidly respond to simple media formulations and are quick to outgrow other organisms. It has been estimated that many fungal taxa are difficult or are unable to be cultured 
with our current methodology which hinders the process of identification and experimentation (Hilton et al. 2016). We emphasize that the importance of culturing is vital for establishing cultural material of both fungal and/or Oomycete pathogens which are needed for screening bean lines for RCR resistance.

As previously mentioned, the DNA sequencing methods we used as identification methods were not always in agreement with all the isolated cultures we collected. In general, the combination of molecularand morphological-based methods, such as the microsatellite and cultural isolation methods we employed here, was better for identifying Macrophomina phaseolina, which was not detected by amplicon sequencing from either the FTA ${ }^{\circledR}$ Cards or direct RCR lesions. DNA-based methods, such as high-throughput Illumina amplicon sequencing and PCRbased microsatellite amplification we used in this study, are the most sensitive technique available for the detection of plant pathogens, due in part to the overall depth of sequencing and the specificity of the oligonucleotide primers designed for Fusarium taxa (Capote et al. 2012). We hypothesize that the poor amplification of numerous Macrophomina phaseolina isolates can be explained by a lack of specificity regarding the oligonucleotide primers and probes, but we have yet to test this hypothesis. Sanger-based sequencing analyses were based on the direct analysis of the genomic DNA of the ITS-2 region which may be variable in the case of M. phaseolina. In addition, the high recovery of M. phaseolina isolates in samples from the Chokwe region in 2015 may be attributed to environmental conditions in the field, such as high humidity and temperature, where M. phaseolina has a high optimal temperature for growth and infection (Songa and Hillocks 1996).

Amplicon sequencing using the Illumina high-throughput platform was used to compare the efficacy of the FTA® Card method for collecting fungi and/or Oomycetes with direct isolation from RCR tissue. The taxonomic diversity assessed by both methods were highly correlated, indicating that FTA $®$ Cards are an acceptable alternative for collection and storage of DNA, particularly in locations where DNA collection via direct placement in liquid buffers may be prohibitive, such as field studies. These results are in agreement with the findings obtained by Ndunguru et al. (2005) who used FTA®Cards for sampling and retrieval of DNA and RNA viruses from plant tissues and conducted molecular analysis on viral diversity. Additionally, the proper use of FTA® Cards for DNA 
collection and storage largely circumvents the security issues related to the import and export of infected plant tissues. These findings demonstrate the importance of using a combination of diagnostic methods to address identification and phylogenetic placement of primary pathogens associated with host-plants. In this study we used specific primers for the ITS-2 and 18S rDNA regions from RCR fungal pathogen isolates, in addition to species-specific oligonucleotide hybridization, which led to the sequencing and analysis of target DNA suited for both taxonomic and phylogenetic assessment of diversity (Herr et al. 2015; Hibbett et al. 2016). However, we stress the importance of culture-based methods for establishing fungal isolate collections that can be used to test for pathogenicity in field and greenhouse experiments with dry beans and assist in breeding efforts to select for pathogen resistance.

A greater amount of genetic variance within fungal populations from a specific location, rather than between the two regions, was most notable in our microsatellite analysis. Despite using the relatively small suite of microsatellites we tested, our results suggest that either gene flow of the fungi exist between the two regions we surveyed or the fungal isolates are broad in their geographic ranges. Even though the Chokwe and Gurue regions are $1200 \mathrm{~km}$ apart, this finding may be explained by a number of factors. For example, many fungi may be seed derived, and an active bean seed exchange between farming locations in Mozambique, as well as with neighboring countries such as Zambia, could be contributing to broad geographic ranges of these fungi. Fusarium oxysporum is known to be seed transmitted (Gargouri et al. 2000; Garibaldi et al. 2004; Pires da Silva et al. 2014) and this species complex consists of morphotypes consisting of similar genotypes with diverse lineages (Pires da Silva et al. 2014; Gordon 2017). Additionally, the F. oxysporum species complex is not well understood and has no identified sexual reproduction system, and, as a result, the diversity among the isolates may be typical resulting in a limited number of clonal lineages on a large geographic scale (Gordon and Martyn 1997; Valverde-Bogantes et al. 2019).

To our knowledge, this is the first study which utilized both molecular and culture methods to determine the primary pathogens associated with RCR disease of bean in Mozambique. The fact that there are similar pathogen profiles in the two main bean-growing regions of Mozambique allows breeders to broadly screen for resistance to Fusarium species, mainly F. oxysporum, and cultural methods can provide the pathogen 
isolates needed for screening across the country as a whole. Currently, the breeding programs in East Africa are predominantly evaluating Pythium spp.; however, the results from this study should provide relevant pathogen information and we hope that it will inform breeding for bean and root rot disease resistance in Mozambique. Lastly, we hope that the findings presented here will provide a basis for future studies of agroecosystem microbiomes (Dundore-Arias et al. 2020) at a finer sampling scale for RCR diseases of dry bean in Mozambique, as well as other tropical and temperate growing regions.

\section{$\diamond \diamond \diamond$}

Supplementary Information Tables S-1 through S-5 follow the References.

Acknowledgments We recognize the help of many regional farmers, most notably R. Joseph, J. Tenga, and E. Langa, as well as many who remain anonymous, in the field identification and collection of beans with RCR symptoms. We acknowledge the help of Edgar Nieto who provided recommendations on heat map visualization tools using the R statistical framework. We also thank the anonymous reviewers who provided feedback and comments on the initial submission of this article.

Author contribution GG-L, CJ, CU, KE, JRS, and JRH were involved in planning and supervised the work; SF, CJ, and GG-L performed the experiments; GG-L and JRH processed the experimental data and designed the figures; SF, GG-L, JRS, and JRH drafted the manuscript. All authors discussed the results and commented on the manuscript.

Funding This work was completed using the Holland Computing Center of the University of Nebraska, which receives support from the Nebraska Research Initiative. JRS recognizes funding from USDA-NIFA (Grant \#11172136) which directly supported this research. JRH acknowledges funding from the US National Air \& Space Administration (Grant \#80NSSC17K0737), the US National Science Foundation (EPSCoR Grant \#1557417), and US National Institute of Justice (Grant \#2017-IJ-CX-0025), as well as start-up funding from the University of Nebraska Agricultural Research Division and the University of Nebraska Office of Research and Economic Development, which indirectly supported this research through the support of research facilities. The funding agencies had no role in study design, data collection and interpretation, or the decision to submit the work for publication.

Data availability The data sets generated and/or analyzed during the current study are available in the following data repository: https://github.com/HerrLab/ Fernandes et al 2019

Conflict of interest The authors have declared no competing interests. 


\section{References}

Abawi GS (1989) Root rots. In: Bean production problems in the tropics. Centro Internacional de Agricultura Tropical (CIAT), Cali, Colombia, $654 \mathrm{p}$

Abawi GS, Pastor-Corrales MA (1990) Root rots of beans in Latin America and Africa: diagnosis, research methodologies, and management strategies. Centro Internacional de Agricultura Tropical (CIAT), Cali, Colombia, $114 \mathrm{p}$

Abd-Elsalam KA, Mohmed IN, Abdel-Sattar MA, Khalil MS, Verreet JA (2003) PCR identification of Fusarium genus based on nuclear ribosomal-DNA sequence data. African Journal of Biotechnology 2:82-85

Alves-Santos FM, Cordeiro-Rodrigues L, Sayagués JM, Martín- Domínguez R, GarcíaBenavides P, Crespo MC, Díaz-Mínguez JM, Eslava AP (2002) Pathogenicity and race characterization of Fusarium oxysporum f. sp. phaseoli isolates from Spain and Greece. Plant Pathology 51:605-611

Babu BK, Srivastava AK, Saxena AK, Arora DK (2007) Identification and detection of Macrophomina phaseolina by using species-specific oligonucleotide primers and probe. Mycologia 99:733-739

Bahkali AH, Abd-Elsalam KA, Guo JR, Khiyami MA, Verreet JA (2012) Characterization of novel di-, tri-, and tetranucleotide microsatellite primers suitable for genotyping various plant pathogenic fungi with special emphasis on Fusaria and Mycospherella graminicola. International Journal of Molecular Sciences 13:2951-2964

Bodah ET (2017) Root rot diseases in plants: a review of common causal agents and management strategies. Agricultural Research and Technology 5:555661

Brasileiro BTRV, Coimbra MRM, Morais MA Jr, Oliveira NT (2004) Genetic variability within Fusarium solani species as revealed by PCR-fingerprinting based on PCR markers. Brazilian Journal of Microbiology 35:205-210

Burgess LW, Summerell BA, Bullock S, Gott KP, Backhouse D (1994) Laboratory manual for Fusarium research. The University of Sydney, Sydney, AUS - Royal Botanic Gardens Press, Sydney

Buruchara R, Camacho L (2000) Common bean reaction to Fusarium oxysporum f. sp. phaseoli, the cause of severe vascular wilt in Central Africa. Journal of Phytopathology 148:39-45

Capote N, Aguado A, Pastrana AM, Sánchez-Torres P (2012) Molecular tools for detection of plant pathogenic fungi and fungicide resistance. In: Molecular tools for detection of plant pathogenic fungi and fungicide resistance. InTechOpen Press. https://doi.org/10.5772/38011

Chaudhary S, Anderson TR, Park SJ, Yu K (2006) Comparison of screening methods for resistance to Fusarium root rot in common beans (Phaseolus vulgaris L.). Journal of Phytopatholgy 154:303-308

Chiodini RJ, Dowd SE, Galandiuk S, Davis B, Glassing A (2016) The predominant site of bacterial translocation across the intestinal mucosal barrier occurs at the advancing disease margin in Crohn's disease. Microbiology 162:1608-1619

Cichy KA, Porch TG, Beaver JS, Cregan P, Fourie D, Glahn RP, Grusak MA, Kamfwa K, Katuuramu DN, McClean P, Mndolwa ES, Nchimbi MS, Pastor-Corrales MA, Miklas 
PN (2015) A Phaseolus vulgaris diversity panel for Andean bean improvement. Journal of Crop Science 55:2149-2160

Clare MM, Melis R, Dereta J, Laing M, Buruchara RA (2010) Identification of sources of resistance to Fusarium root rot among selected common bean lines in Uganda. Journal of Animal and Plant Sciences 7:876-891

Cole JR, Chai B, Farris RJ, Wang Q, Kulam SA, McGarrell DM, Garrity GM, Tiedje JM (2005) The Ribosomal Database Project (RDP-II): sequences and tools for highthroughput rRNA analysis. Nucleic Acids Research 33:D294-D296

Core Team R (2018) R: a language and environment for statistical computing. R Foundation for Statistical Computing, Vienna https://www.R-project.org/

DeSantis TZ, Hugenholtz P, Larsen N, Rojas M, Brodie EL, Keller K, Huber T, Dalevi D, Hu P, Andersen PL (2006) Greengenes, a chimera-checked 16S rRNA gene database and workbench compatible with ARB. Applied and Environmental Microbiology 72:5069-5072

Dhingra OD, Sinclair JB (1978) Biology and pathology of Macrophomina phaseolina. Imprensa Universitária, Universidade Federal de Viçosa, Viçosa, 166 pp

Drummond AJ, Rambaut A (2007) BEAST: Bayesian evolutionary analysis by sampling trees. BMC Evolutionary Biology 7:214

Dugan FM (2006) The identification of fungi: an illustrated introduction with keys, glossary and guide to literature. APS Press, St Paul, $176 \mathrm{pp}$

Dundore-Arias JP, Eloe-Fadrosh EA, Schriml LM, Beattie GA, Brennan FP, Busby PE, Calderon RB, Castle SC, Emerson JB, Everhart SE,

Eversole K, Frost KE, Herr JR, Huerta AI, Iyer-Pascuzzi AS, Kalil AK, Leach JE, Leonard J, Maul JE, Prithiviraj B, Potrykus M, Redekar NR, Rojas JA, Silverstein KAT, Tomso DJ, Tringe SG, Vinatzer BA, Kinkel LL (2020) Community-driven metadata standards for agricultural microbiome research. Phytobiomes Journal 4:115-121

Edgar RC (2004) MUSCLE: multiple sequence alignment with high accuracy and high throughput. Nucleic Acids Research 32:1792-1797

Estevez de Jensen CE, Kurle JE, Percich JA (2004) Integrated management of edaphic and abiotic factors limiting yield of irrigation soybean and dry bean in Minnesota. Field Crops Research 86:211-224

Farrow A, Musoni D, Cook S, Buruchara R (2011) Assessing the risk of root rots in common beans in East Africa using simulated, estimated, and observed daily rainfall data. Experimental Agriculture 47:357-373

Fisher NL, Burgess LW, Toussoun TA, Nelson PE (1982) Carnation leaves as a substrate for preserving cultures of Fusarium species. Journal of Phytopathology 72:151-152

Gargouri S, Hajlaoui MR, Abdennadher M, Marrakchi M (2000) Isolation and morphological and molecular identification of Fusarium spp. transmitted by watermelon seeds. Bulletin OEPP 30:217-222

Garibaldi A, Gilardi G, Gullino ML (2004) Seed transmission of Fusarium oxysporum $\mathrm{f}$. sp. lactucae. Phytoparasitica 32:61-65

Gordon TR (2017) Fusarium oxysporum and the Fusarium wilt syndrome. Annual Review of Phytopathology 55:23-39

Gordon TR, Martyn RD (1997) The evolutionary biology of Fusarium oxysporum. Annual Review of Phytopathology 35:111-128 
Guillemaut C, Edel-Hermann V, Camporota P, Alabouvette C, Richard-Molard M, Steinberg C (2003) Typing of anastomosis groups of by restriction analysis of ribosomal DNA. Can J Microbiol 49:556-568

Hammer O, Harper DAT, Ryan PD (2001) PAST: paleontological statistics software package for education and data analysis. Palaeontologia Electronica 4:1-9

Harveson RM, Smith JA, Stroup WW (2005) Improving root health and yield of dry bean on Nebraska panhandle with a new technique for reducing soil compaction. Plant Disease 89:279-284

Herr JR, Öpik M, Hibbett DS (2015) Towards the unification of sequencebased classification and sequence-based identification of host-associated microorganisms. New Phytologist 205:27-31

Hibbett D, Abarenkov K, Kõljalg U, Öpik M, Chai B, Cole J, Wang Q, Crous P, Robert V, Helgason T, Herr JR, Kirk P, Lueschow S, O’Donnell K, Nilsson RH, Oono R, Schoch C, Smyth C, Walker DM, Porras-Alfaro A, Taylor JW, Geiser DM (2016) Sequencebased classification and identification of fungi. Mycologia 108:1049-1068

Hilton SK, Castro-Nallar E, Pérez-Losada M, Toma I, McCaffrey TA, Hoffman EP, Siegel MO, Simon GL, Johnson WE, Crandall KA (2016) Metataxonomic and metagenomic approaches vs. culture-based techniques for clinical pathology. Frontiers in Microbiology 7:484

Kamvar ZN, Tabima JF, Grünwald NJ (2014) Poppr: an R package for genetic analysis of populations with clonal, partially clonal, and/or sexual reproduction. PeerJ 2:e281

Kang HW, Park DS, Go SJ, Eun MY (2002) Fingerprinting of diverse genomes using PCR with universal rice primers generated from repetitive sequence of Korean weedy rice. Molecules and Cells 13:281-287

Leslie JF, Summerell BA (2006) The Fusarium laboratory manual. Wiley-Blackwell Publishing, Hoboken, NJ, pp 388

Letunic I, Bork P (2016) Interactive tree of life (iTOL) version 3: an online tool for the display and annotation of phylogenetic and other trees. Nucleic Acids Research 44:W242-W245

Lieckfeldt E, Meyer W, Börner T (1993) Rapid identification and differentiation of yeasts by DNA and PCR fingerprinting. J Basic Microbiol 33(6):413-425

Lofgren LA, LeBlanc NR, Certano AK, Nachtigall J, LaBine KM, Riddle J, Broz K, Dong Y, Bethan B, Kafer CW, Kistler HC (2018) Fusarium graminearum: pathogen or endophyte of North American grasses? New Phytologist 217:1203-1212

Martin FN (2000) Phylogenetic relationships among some Pythium species inferred from sequence analysis of the mitochondrially encoded cytochrome oxidase II gene. Mycologia 92:711-727

McDonald D, Price MN, Goodrich J, Nawrocki EP, DeSantis TZ, Probst A, Andersen GL, Knight R, Hugenholtz P (2012) An improved Greengenes taxonomy with explicit ranks for ecological and evolutionary analyses of bacteria and archaea. The ISME Journal 6:610-618

Mukuma C, Godoy-Lutz G, Eskridge K, Steadman J, Urrea C, Muimui K (2020) Use of culture and molecular methods for identification and characterization of dry bean fungal root rot pathogens in Zambia. Tropical Plant Pathology 45:385-396 
Nair DN, Padmavathy S (2014) Impact of endophytic microorganisms on plants, environment, and humans. The Scientific World Journal 2014:250693

Narayanasamy P (2011) Detection of fungal pathogens in plants. In: Microbial plant pathogens-detection and disease diagnosis. Springer, Dordrecht

Ndunguru J, Taylor NJ, Yadav J, Aly H, Legg JP, Aveling T, Fauquet CM (2005) Application of FTA technology for sampling, recovery and molecular characterization of viral pathogens and virus-derived transgenes from plant tissues. Virology Journal 2:45

Nei M (1973) Analysis of gene diversity in subdivided populations. Proceedings of the National Academy of Sciences USA 70:3321-3323

Neuwirth E (2014) RColorBrewer: ColorBrewer palettes. R package version 1:1-2 https://CRAN.R-project.org/package=RColorBrewer

Nzungize J, Gepts P, Buruchara R, Buah S, Ragama P, Busogoro JP, Baudoin JP (2011a) Pathogenic and molecular characterization of Pythium species inducing root rot symptoms of common bean in Rwanda. African Journal of Microbiological Research 5:1169-1181

Nzungize J, Gepts P, Buruchara R, Male A, Ragama P, Busogoro JP, Baudoin JP (2011b) Introgression of Pythium root rot resistance gene into Rwandan susceptible common bean cultivars. African Journal of Plant Sciences 5:193-200

O'Donnell K, Kistler HC, Cigelnik E, Ploetz RC (1998) Multiple evolutionary origins of the fungus causing Panama disease of banana: concordant evidence from nuclear and mitochondrial gene genealogies. Proceedings of the National Academy of Sciences USA 95: 2044-2049

Paparu P, Acur A, Kato F, Acam C, Nakibuule J, Musoke S, Nikalubo S, Mukankusi $C$ (2018) Prevalence and incidence of four common bean root rots in Uganda. Experimental Agriculture 54:888-900

Park B, Park J, Cheong KC, Choi J, Jung K, Kim D, Lee YH, Ward TJ, O’Donnell K, Geiser DM, Kang S (2010) Cyber infrastructure for Fusarium: three integrated platforms supporting strain identification, phylogenetics, comparative genomics, and knowledge sharing. Nucleic Acids Research 39:D640-D646

Pastor-Corrales MA, Abawi GS (1987) Reaction of selected bean germplasm to infection by Fusarium oxysporum $\mathrm{f}$ sp. phaseoli. Journal of Plant Disease 71:990-993

Peakall R, Smouse PE (2006) GenAlEx 6: genetic analysis in Excel - population genetic software for teaching and research. Molecular Ecology Notes 6:288-295

Pires da Silva R, Vechiato MH, Harakava R (2014) EF-1 $\alpha$ gene and IGS rDNA sequencing of Fusarium oxysporum f. sp. vasinfectum and F. oxysporum f. sp. phaseoli reveals polyphyletic origin of strains. Tropical Plant Pathology 39:64-73

Quast C, Pruesse E, Yilmaz P, Gerken J, Schweer T, Yarza P, Peplies J, Glöckner FO (2012) The SILVA ribosomal RNA gene database project: improved data processing and web-based tools. Nucleic Acids Research 41:D590-D596

Rognes T, Flouri T, Nichols B, Quince C, Mahé F (2016) VSEARCH: a versatile opensource tool for metagenomics. PeerJ 4:e2584

Rusuku G, Buruchara RA, Gatabazi M, Pastor-Corrales MA (1997) Occurrence and distribution in Rwanda of soil-borne fungi pathogenic to the common bean. Journal of Plant Disease 81:445-449 
Shannon CE, Wiener W(1963) The mathematical theory of communication.

University of Illinois Press, Urbana, IL

Simpson EH (1949) Measurement of diversity. Nature 163:688

Songa W, Hillocks RJ (1996) Charcoal rot in common bean with special reference to Kenya. International Journal of Pest Management 42: 213-219

Valverde-Bogantes E, Bianchini A, Herr JR, Rose DJ, Wegulo SN, Hallen-Adams HE (2019) Recent population changes of Fusarium head blight pathogens: drivers and implications. Canadian Journal of Plant Pathology 42:315-329

Walker TS, Pitoro R, Tomo A, Sitoe I, Salencia C, Mahanzule R, Donovan C, Mazuze FM (2006) Priority setting for public-sector agricultural research in Mozambique with the National Agricultural Survey Data (No. 1093-2016-88001)

Watanabe T (2010) Morphologies of cultured fungi and key to species. In: Pictorial atlas of soil and seed fungi - Morphologies of cultured fungi and key to species, 3rd Edition. CRC Press, Florida pp 426. https://www.routledge.com/PictorialAtlas-of-Soil-and-Seed-Fungi-Morphologies-of-Cultured-Fungi-and/Watanabe/p/ book/9781439804193

White TJ, Bruns T, Lee S, Taylor TW (1990) Amplification and direct sequencing of fungal ribosomal RNA genes for phylogenetics. In: PCR protocols: a guide to methods and applications, Academic Press, Inc., New York. pp. 315-322

Wickham H (2016) ggplot2: elegant graphics for data analysis. Springer-Verlag Press, New York

Wortmann CS, Kirkby RA, Eledu CA, Allen DJ (1998) Atlas of common bean (Phaseolus vulgaris L.) production in Africa. Centro Internacional de Agricultura Tropical (CIAT). CIAT publication number 297, Cali, $131 \mathrm{p}$ 
Table S-1 - Table summary of microsatellite AMOVA analysis comparing Fusarium oxysporum populations isolated at the Chokwe and Gurue locations.

Table S-2 - Table of within population genetic diversity indicators of $F$. oxysporum isolates from the sampling locations of Chokwe and Gurue based on microsatellite primer amplification.

Table S-3 - Table of plant and soil sampling locations, soil metadata characteristics, and climate information for collection sites in this study.

Table S-4 - Table of oligonucleotide primer sequences used in this study.

Table S-5 - Table of information on each isolate obtained from RCR tissue culture of bean plants collected in Mozambique and the closest database match of the NCBI accession number. 
Table S-1

\begin{tabular}{|c|c|c|c|c|c|}
\hline Source of Variation & $\begin{array}{l}\text { Degrees } \\
\text { of } \\
\text { Freedom }\end{array}$ & SS & $\begin{array}{l}\text { Mean } \\
\text { Square }\end{array}$ & $\begin{array}{l}\text { Estimated } \\
\text { Variance }\end{array}$ & $\begin{array}{c}\% \\
\text { Variation }\end{array}$ \\
\hline \multicolumn{6}{|c|}{ URP2R } \\
\hline Between populations & 1 & 19.453 & 19.45 & 0.596 & 21 \\
\hline Within populations & 62 & 138.641 & 2.236 & 2.236 & 79 \\
\hline Total & 63 & 158.09 & & 2.82 & 100 \\
\hline \multicolumn{6}{|l|}{ Fst value 0.21} \\
\hline \multicolumn{6}{|c|}{$(\mathrm{AGG})_{5}$} \\
\hline Between populations & 1 & 17.942 & 17.94 & 0.448 & 10 \\
\hline Within populations & 90 & 351.797 & 3.909 & 3.909 & 90 \\
\hline Total & 91 & 369.739 & & 4.357 & 100 \\
\hline \multicolumn{6}{|l|}{ Fst value 0.10} \\
\hline \multicolumn{6}{|c|}{$(\mathrm{GTG})_{5}$} \\
\hline Between populations & 1 & 12.814 & 12.814 & 0.282 & 7 \\
\hline Within populations & 71 & 251.377 & 3.541 & 3.541 & 93 \\
\hline Total & 72 & 264.192 & 3.823 & 3.823 & 100 \\
\hline Fst value 0.07 & & & & & \\
\hline \multicolumn{6}{|c|}{$(\mathrm{ACG})_{5}$} \\
\hline Between populations & 1 & 2.931 & 2.937 & 0.018 & 1 \\
\hline Within populations & 89 & 208.642 & 2.344 & 2.344 & 99 \\
\hline Total & 90 & 211.560 & & 2.362 & 100 \\
\hline Fst value 0.01 & & & & & \\
\hline
\end{tabular}

$\mathrm{P}=0.01$ 


\section{Table S-2}

\begin{tabular}{|l|l|l|l|l|l|l|l|l|l|}
\hline \multirow{2}{*}{\begin{tabular}{l|l|l|l|l|l|} 
Population \\
\cline { 2 - 9 }
\end{tabular}} & Chokwe & Gurue & Chokwe & Gurue & Chokwe & Gurue & \multicolumn{2}{c|}{ Chokwe } & Gurue \\
\hline No. bands & 16 & 16 & 17 & 21 & 18 & 26 & 19 & 27 \\
\hline $\begin{array}{l}\text { No. bands } \\
\text { Freq. >=5\% }\end{array}$ & 16 & 11 & 17 & 17 & 12 & 15 & 19 & 25 \\
\hline $\begin{array}{l}\text { No. Private } \\
\text { bands }\end{array}$ & 3 & 3 & 2 & 6 & 1 & 9 & 1 & 9 \\
\hline $\begin{array}{l}\text { \% of } \\
\text { polymorphism }\end{array}$ & 55.17 & 55.17 & 58.72 & 72.41 & 62.07 & 89.66 & 65.2 & 93.10 \\
\hline Mean $^{\mathrm{d}}$ & 0.211 & 0.129 & 0.225 & 0.227 & 0.153 & 0.160 & 0.196 & 0.282 \\
& \pm 0.039 & \pm 0.032 & \pm 0.040 & \pm 0.036 & \pm 0.03 & \pm 0.027 & \pm 0.034 & \pm 0.030 \\
\hline Mean uh $^{\mathrm{e}}$ & 0.241 & 0.132 & 0.247 & 0.232 & 0.161 & 0.162 & 0.207 & 0.286 \\
& \pm 0.044 & \pm 0.033 & \pm 0.044 & \pm 0.037 & \pm 0.032 & \pm 0.028 & \pm 0.035 & \pm 0.031 \\
\hline $\mathrm{I}^{\mathrm{f}}$ & 0.312 & 0.206 & 0.33 & 0.34 & 0.247 & 0.268 & 0.304 & 0.434 \\
& \pm 0.056 & \pm 0.046 & \pm 0.056 & \pm 0.051 & \pm 0.04 & \pm 0.03 & \pm 0.049 & \pm 0.04 \\
\hline
\end{tabular}

${ }^{\mathrm{a}}=$ No. of different bands

${ }^{b}=$ No. of different bands with a frequency $>=5 \%$

${ }^{c}=$ No. of bands unique to a single population

${ }^{\mathrm{d}}=$ Diversity $=1-\left(\mathrm{p}^{\wedge} 2+\mathrm{q}^{\wedge} 2\right)$

${ }^{\mathrm{e}}=$ Unbiased diversity $=(\mathrm{N} /(\mathrm{N}-1)) * \mathrm{~h}$

f = Shannon's Information index

$=-1 *(\mathrm{p} * \operatorname{Ln}(\mathrm{p})+\mathrm{q} * \operatorname{Ln}(\mathrm{q}))$

where for Haploid Binary data, $p$

$=$ Band Freq. and $\mathrm{q}=1-\mathrm{p}$ 
Table S-3

\begin{tabular}{|c|c|c|c|c|c|c|c|}
\hline \multicolumn{2}{|l|}{ Collection } & \multicolumn{3}{|c|}{ Coordinates (DMS) } & \multicolumn{3}{|c|}{ Soils characteristics } \\
\hline Site & Year & Latitude & Longitude & $\begin{array}{c}\text { Altitude } \\
(\text { masl) }\end{array}$ & Soil types & $\begin{array}{c}\text { Soil organic } \\
\text { matter* }\end{array}$ & Climate \\
\hline $\begin{array}{c}\text { ADP-NE Root rot nursery } \\
\text { in Mutequelesse - Gurue, } \\
\text { Zambezia Province }\end{array}$ & $\begin{array}{l}2014 \\
2015\end{array}$ & $15^{\circ} 19^{\prime} 2.55^{\prime \prime} \mathrm{S}$ & $36^{\circ} 42^{\prime} 8.01^{\prime \prime} \mathrm{E}$ & 690 & Ferrossols & Medium & $\begin{array}{l}\text { Cool, sub- } \\
\text { humid }\end{array}$ \\
\hline $\begin{array}{l}\text { ADP-NE Root rot nursery } \\
\text { field- Chokwe Research } \\
\text { Station, Gaza Province }\end{array}$ & $\begin{array}{l}2014 \\
2015\end{array}$ & $24^{\circ} 30^{\prime} 15^{\prime \prime} \mathrm{S}$ & $33^{\circ} 00^{\prime} 11^{\prime \prime} \mathrm{E}$ & 34 & $\begin{array}{c}\text { Salic Fluvisol } \\
\text { (Mananga) }\end{array}$ & Medium to rich & Semi-arid \\
\hline $\begin{array}{l}\text { Farmer's fields- Chate, } \\
\text { Chokwe, Gaza Province }\end{array}$ & $\begin{array}{l}2014, \\
2015\end{array}$ & $24^{\circ} 21^{\prime} 52^{\prime \prime} \mathrm{S}$ & $32^{\circ} 50^{\prime} 32^{\prime \prime} \mathrm{E}$ & 43 & $\begin{array}{l}\text { Eutric Fluvisol } \\
\text { (Mananga) }\end{array}$ & Medium to rich & Semi-arid \\
\hline $\begin{array}{c}\text { Farmer's field- Chissano, } \\
\text { Gaza Province }\end{array}$ & 2014 & N/D & N/D & $\mathrm{N} / \mathrm{D}$ & $\begin{array}{l}\text { Salic Fluvisol } \\
\text { (Mananga) }\end{array}$ & Medium to rich & Semi-arid \\
\hline $\begin{array}{l}\text { DP-NE Root rot nursery } \\
\text { field- Chokwe Research } \\
\text { Station, Gaza Province }\end{array}$ & 2015 & $24^{\circ} 30^{\prime} 20^{\prime \prime} \mathrm{S}$ & $33^{\circ} 00^{\prime} 07^{\prime \prime} \mathrm{E}$ & 33 & $\begin{array}{l}\text { Salic Fluvisol } \\
\text { (Mananga) }\end{array}$ & Medium to rich & Semi-arid \\
\hline $\begin{array}{l}\text { Farmer's field- Camul- } \\
\text { Chokwe, Gaza Province }\end{array}$ & 2015 & $24^{\circ} 32^{\prime} 13^{\prime \prime} \mathrm{S}$ & $33^{\circ} 01^{\prime} 09^{\prime \prime} \mathrm{E}$ & 31 & $\begin{array}{l}\text { Salic Fluvisol } \\
\text { (Mananga) }\end{array}$ & Medium to rich & Semi-arid \\
\hline $\begin{array}{l}\text { Farmer's field- Camul- } \\
\text { Chokwe, Gaza Province }\end{array}$ & 2015 & $24^{\circ} 32^{\prime} 11^{\prime \prime} \mathrm{S}$ & $33^{\circ} 01^{\prime} 05^{\prime \prime} \mathrm{E}$ & 31 & $\begin{array}{c}\text { Salic Fluvisol } \\
\text { (Mananga) }\end{array}$ & Medium to rich & Semi-arid \\
\hline
\end{tabular}

$*$ Medium $=1.6 \%-3.0 \%$ organic matter, Rich $=3.1 \%-6.0 \%$ organic matter 
Table S-4

\begin{tabular}{|c|c|c|c|c|}
\hline Code & $\begin{array}{l}\text { Target } \\
\text { Gene }\end{array}$ & Primer Sequence $\left(5^{\prime} \rightarrow 3^{\prime}\right)$ & $\begin{array}{l}\text { Annealing } \\
\text { Temperature } \\
{ }^{\circ} \mathrm{C}\end{array}$ & Source \\
\hline $\begin{array}{l}\text { FM } 66 \\
\text { FM } 58 \\
\text { COX II }\end{array}$ & Cytochrome oxidase Il & $\begin{array}{l}\text { TAGGATTTCAAGATCCTGC } \\
\text { CCACAAATTTCACTACATTGA }\end{array}$ & $52^{\circ} \mathrm{C}$ & $\begin{array}{l}\text { Martin, } \\
2000\end{array}$ \\
\hline $\begin{array}{l}\text { MpkF1 } \\
\text { MpkR1 }\end{array}$ & $\begin{array}{l}\text { Internal Transcribed } \\
\text { Spacer rRNA }\end{array}$ & $\begin{array}{l}\text { CCGCCAGAGGACTATCAAAC } \\
\text { CGTCCGAAGCGAGGTGTATT }\end{array}$ & $56^{\circ} \mathrm{C}$ & $\begin{array}{l}\text { Kishore } \\
\text { Babbu } e t \\
\text { al., } 2007\end{array}$ \\
\hline $\begin{array}{l}\text { ITSFuF } \\
\text { ITSFuR }\end{array}$ & $\begin{array}{l}\text { Internal Transcribed } \\
\text { Spacer rRNA }\end{array}$ & $\begin{array}{l}\text { CAACTCCCAAACCCCTGTGA } \\
\text { GCGACGATTACCAGTAACGA }\end{array}$ & $58^{\circ} \mathrm{C}$ & $\begin{array}{l}\text { Ed Elsalam } \\
\text { KA et al., } \\
2003\end{array}$ \\
\hline EF1 & $\begin{array}{c}\text { Translation Elongation } \\
\text { Factor }(1-\alpha)\end{array}$ & $\begin{array}{l}\text { ATGGGTAAGGA(A/G)GACAA } \\
\text { GAC } \\
\text { GGA(G/A)GTACCAGT(G/C)AT } \\
\text { CATGTT }\end{array}$ & $53^{\circ} \mathrm{C}$ & $\begin{array}{l}\text { O'Donnell } \\
\text { et al., } 1998\end{array}$ \\
\hline $\begin{array}{l}\mathrm{R} 1 \\
\mathrm{R} 4\end{array}$ & $\begin{array}{l}\text { Internal Transcribed } \\
\text { Spacer rRNA }\end{array}$ & $\begin{array}{l}\text { CCTGTGCACCTGTGAGACAG } \\
\text { TGTCCAAGTCAATGGACTAT }\end{array}$ & $56^{\circ} \mathrm{C}$ & $\begin{array}{l}\text { Camporota } \\
\text { et al., } 2000\end{array}$ \\
\hline $\begin{array}{l}\text { ITS5 } \\
\text { ITS4 }\end{array}$ & $\begin{array}{l}\text { Internal Transcribed } \\
\text { Spacer rRNA }\end{array}$ & $\begin{array}{l}\text { GGAAGTAAAAGTCGTAACAA } \\
\text { GG } \\
\text { TCCTCCGCTTATTGATATGC }\end{array}$ & $55^{\circ} \mathrm{C}$ & $\begin{array}{l}\text { White } e t \\
\text { al., } 1990\end{array}$ \\
\hline URP2R & & CCCAGCAACTGATCGCACAC & $45^{\circ} \mathrm{C}$ & $\begin{array}{l}\text { Khan et al., } \\
\quad 2002\end{array}$ \\
\hline$(\mathrm{GTG})_{5}$ & Entire genome & GTGGTGGTGGTGGTG & $50^{\circ} \mathrm{C}$ & $\begin{array}{l}\text { Brasileiro } \\
\text { et al., } 2004\end{array}$ \\
\hline$(\mathrm{ACG})_{5}$ & & ACGACGACGACGACG & $52^{\circ} \mathrm{C}$ & \\
\hline$(\mathrm{AGG})_{5}$ & & AGGAGGAGGAGGAGG & $50^{\circ} \mathrm{C}$ & $\begin{array}{l}\text { Bahkali } \\
\text { et al., } 2012\end{array}$ \\
\hline
\end{tabular}


Table S-5

\begin{tabular}{|c|c|c|c|c|c|}
\hline $\begin{array}{l}\text { Isolate } \\
\text { ID }\end{array}$ & 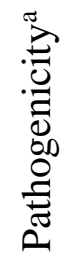 & $\begin{array}{l}\text { Location/ Year } \\
\text { of Collection }\end{array}$ & $\begin{array}{c}\text { Source } \\
\text { Bean } \\
\text { line/Variety }\end{array}$ & Species & $\begin{array}{c}\text { NCBI } \\
\text { GenBank } \\
\text { accession } \\
\text { closest match }^{\mathrm{b}}\end{array}$ \\
\hline M1 & NP & Chokwe/2014 & Mbulamtwe & Alternaria alternata & KT223359.1 \\
\hline M2 & NP & Chokwe/2014 & Mbulamtwe & Alternaria alternata & KT223325.1 \\
\hline M3 & $P$ & Chokwe/2014 & Mbulamtwe & Alternaria alternata & KT274695.1 \\
\hline M4 & NP & Chokwe/2014 & Mbulamtwe & Alternaria sp. & EF432261.1 \\
\hline M5 & NP & Chokwe/2014 & Mbulamtwe & No similarity found & \\
\hline M6 & NP & Chokwe/2014 & Mbulamtwe & Cladosporium sp. & KC178629.1 \\
\hline M7 & NP & Chokwe/2014 & Kisapuri & Alternaria alternata & KF881762.1 \\
\hline M8 & NP & Chokwe/2014 & Kisapuri & Alternaria alternata & KF881759.1 \\
\hline M9 & NP & Chokwe/2014 & Kisapuri & Alternaria alternata & KC178652.1 \\
\hline M10 & NP & Chokwe/2014 & Kisapuri & Alternaria alternata & KT192329.1 \\
\hline M11 & NP & Chokwe/2014 & Kisapuri & Alternaria alternata & KU377991.1 \\
\hline M12 & $\mathrm{P}$ & Chokwe/2014 & Kisapuri & Alternaria alternata & KP278185.1 \\
\hline M13 & NP & Chokwe/2014 & Kisapuri & Alternaria alternata & KT192329.1 \\
\hline M14 & NP & Chokwe/2014 & Kisapuri & Alternaria arborescens & KM246282.1 \\
\hline M15 & $\mathrm{P}$ & Chokwe/2014 & Kisapuri & Alternaria alternata & KJ605840.1 \\
\hline M16 & NP & Chokwe/2014 & Kisapuri & Alternaria arborescens & KJ609138.1 \\
\hline M17 & $\mathrm{P}$ & Chokwe/2014 & Kisapuri & Alternaria alternata & JQ676197.1 \\
\hline M18 & NP & Chokwe/2014 & Kisapuri & Alternaria alternata & KJ739880.1 \\
\hline M19 & $P$ & Chokwe/2014 & Kisapuri & Alternaria alternata & HQ846574.1 \\
\hline M20 & NP & Chokwe/2014 & Incomparable & Fusarium oxysporum & KJ439205.1 \\
\hline M21 & NP & Chokwe/2014 & Incomparable & Alternaria macrospora & DQ156342.1 \\
\hline M22 & $\mathrm{P}$ & Chokwe/2014 & Incomparable & Alternaria alternata & KP271958.1 \\
\hline M23 & NP & Chokwe/2014 & $\begin{array}{l}\text { Maharage } \\
\text { Makubwa }\end{array}$ & Cladosporium sp. & KC178629.1 \\
\hline
\end{tabular}




\begin{tabular}{|c|c|c|c|c|c|}
\hline M24 & NP & Chokwe/2014 & $\begin{array}{l}\text { Maharage } \\
\text { Makubwa }\end{array}$ & Alternaria arborescens & KJ609138.1 \\
\hline M25 & NP & Chokwe/2014 & Sodan & Chaetomium globosum & KU375642.1 \\
\hline M26 & NP & Chokwe/2014 & Kablanketi & $\begin{array}{l}\text { Mucor circinelloides } \mathrm{f} . \\
\text { lusitanicus }\end{array}$ & JF439687.1 \\
\hline M27 & NP & Chokwe/2014 & P1321094-D & Alternaria alternata & KJ739872.1 \\
\hline M28 & $\mathrm{P}$ & Chokwe/2014 & P1321094-D & Alternaria alternata & KX115415.1 \\
\hline M29 & NP & Chokwe/2014 & NE34-12-20 & Curvalaria lunata & KF498867.1 \\
\hline M30 & NP & Chokwe/2014 & NE34-12-20 & Curvalaria lunata & KF498867.1 \\
\hline M31 & NP & Chokwe/2014 & NE34-12-20 & Curvalaria lunata & KY404178.1 \\
\hline M32 & NP & Chokwe/2014 & NE34-12-45 & Alternaria alternata & KJ605840.1 \\
\hline M33 & $\mathrm{P}$ & Chokwe/2014 & NE34-12-45 & Alternaria alternata & KT274695.1 \\
\hline M34 & NP & Chate $/ 2014$ & PAN 127 & $\begin{array}{l}\text { Cladosporium } \\
\text { halotolerans }\end{array}$ & LN834369.1 \\
\hline M35 & $\mathrm{P}$ & Chate $/ 2014$ & PAN 127 & Fusarium oxysporum & KJ528881.1 \\
\hline M36 & $\mathrm{P}$ & Chate $/ 2014$ & PAN 127 & $\begin{array}{l}\text { Fusarium oxysporum f. } \\
\text { sp. ciceris }\end{array}$ & HG423346.1 \\
\hline M37 & NP & Chate $/ 2014$ & PAN 127 & Fusarium oxysporum & KX196809.1 \\
\hline M38 & NP & Chate $/ 2014$ & PAN 127 & Chaetomium globosum & KR063144.1 \\
\hline M39 & NP & Chate $/ 2014$ & PAN 128 & $\begin{array}{l}\text { Cladosporium } \\
\text { cladosporioides }\end{array}$ & KX664415.1 \\
\hline M40 & NP & Chate $/ 2014$ & PAN 128 & $\begin{array}{l}\text { Cladosporium } \\
\text { tenuissimum }\end{array}$ & EU272531.1 \\
\hline M41 & $\mathrm{P}$ & Chate $/ 2014$ & PAN 128 & Fusarium solani & KM235740.1 \\
\hline M42 & $\mathrm{P}$ & Chate /2014 & PAN 128 & Fusarium oxysporum & KU872849.1 \\
\hline M43 & NP & Chate $/ 2014$ & PAN 127 & $\begin{array}{l}\text { Marasmius } \\
\text { brunneoaurantiacus } \\
\text { voucher }\end{array}$ & KX149014.1 \\
\hline M44 & NP & Chate /2014 & PAN 127 & $\begin{array}{l}\text { Marasmius } \\
\text { brunneoaurantiacus } \\
\text { voucher }\end{array}$ & KX149014.1 \\
\hline M45 & NP & Chate $/ 2014$ & PAN 127 & Fusarium verticillioides & KF897854.1 \\
\hline M46 & $\mathrm{P}$ & Chate /2014 & PAN 127 & Fusarium oxysporum & KU872849.1 \\
\hline
\end{tabular}




\begin{tabular}{|c|c|c|c|c|c|}
\hline M47 & $\mathrm{P}$ & Chate /2014 & PAN 127 & Fusarium nyagamai & HF546381.1 \\
\hline M48 & NP & Chokwe/2014 & PAN 127 & Alternaria alternata & KT192402.1 \\
\hline M49 & NP & Chokwe/2014 & PAN 127 & Alternaria alternata & KF881762.1 \\
\hline M50 & NP & Chokwe/2014 & PAN 127 & Alternaria alternata & KT192393.1 \\
\hline M51 & $\mathrm{P}$ & Chokwe/2014 & PAN 127 & Alternaria alternata & KJ739880.1 \\
\hline M52 & $\mathrm{P}$ & Chissano/2014 & PAN 148 & Fusarium oxysporum & KU872840.1 \\
\hline M53 & $\mathrm{P}$ & Chissano/2014 & PAN 148 & Fusarium oxysporum & GU724513.1 \\
\hline M54 & NP & Chissano/2014 & PAN 148 & Fusarium oxysporum & KP050556.1 \\
\hline M55 & $\mathrm{P}$ & Chissano/2014 & PAN 148 & Fusarium oxysporum & KM519660.1 \\
\hline M56 & NP & Chissano/2014 & PAN 148 & Fusarium equiseti & KR094440.1 \\
\hline M57 & $\mathrm{P}$ & Chissano/2014 & PAN 148 & Fusarium oxysporum & KX196807.1 \\
\hline M58 & $\mathrm{P}$ & Chissano/2014 & PAN 148 & Fusarium oxysporum & JF300424.1 \\
\hline M59 & NP & Chissano/2014 & PAN 148 & Fusarium oxysporum & KX196807.1 \\
\hline M60 & $\mathrm{P}$ & Chissano/2014 & PAN 148 & Fusarium oxysporum & GU724513.1 \\
\hline M61 & $\mathrm{P}$ & Chissano/2014 & Icapijāo & Fusarium solani & HQ439152.1 \\
\hline M62 & $\mathrm{P}$ & Chissano/2014 & Icapijāo & Fusarium solani & EU625405.1 \\
\hline M63 & $\mathrm{P}$ & Chissano/2014 & Icapijāo & Fusarium solani & JQ277276.1 \\
\hline M64 & $\mathrm{P}$ & Chissano/2014 & Icapijāo & Fusarium solani & KC764913.1 \\
\hline M65 & $\mathrm{P}$ & Chissano/2014 & Icapijāo & Fusarium oxysporum & KU056819.1 \\
\hline M66 & $\mathrm{P}$ & Chissano/2014 & Icapijāo & Fusarium solani & JN006817.1 \\
\hline M67 & NP & Chissano/2014 & Icapijāo & Rhizoctonia zeae & GQ221863.1 \\
\hline M68 & NP & Chissano/2014 & Icapijāo & Rhizoctonia zeae & GQ221863.1 \\
\hline M69 & NP & Chissano/2014 & Icapijāo & Rhizoctonia zeae & GQ221863.1 \\
\hline M70 & NP & Chissano/2014 & Icapijāo & Fusarium solani & KJ528882.1 \\
\hline M71 & $\mathrm{NP}$ & Chissano/2014 & AP 89 & Thielavia terricola & KJ921610.1| \\
\hline M72 & NP & Chissano/2014 & AP 89 & Thielavia terricola & GU966509.1 \\
\hline M73 & $\mathrm{P}$ & Chissano/2014 & AP 89 & Fusarium oxysporum & KX196807.1 \\
\hline M74 & NP & Chissano/2014 & AP 89 & Chaetomium funicola & KM979902.1 \\
\hline M75 & $\mathrm{P}$ & Chissano/2014 & AP 89 & Fusarium solani & KM235740.1 \\
\hline
\end{tabular}




\begin{tabular}{|c|c|c|c|c|c|}
\hline M76 & NP & Chissano/2014 & Bonus & Epicocum nigrum & KF881763.1 \\
\hline M77 & NP & Chissano/2014 & Bonus & Epicocum nigrum & KF881763.1 \\
\hline M78 & NP & Chissano/2014 & Bonus & Epicocum nigrum & KX664321.1 \\
\hline M79 & NP & Chissano/2014 & Bonus & Epicocum nigrum & KM519661.1 \\
\hline M80 & NP & Chissano/2014 & Bonus & Epicocum nigrum & KM519661.1 \\
\hline M81 & NP & Chissano/2014 & Bonus & Epicocum nigrum & KM519661.1 \\
\hline M82 & $\mathrm{P}$ & Chissano/2014 & LPA 91 & Fusarium solani & KF918580.1 \\
\hline M83 & NP & Chissano/2014 & LPA 91 & Fusarium oxysporum & KU872849.1 \\
\hline M84 & NP & Chissano/2014 & LPA 91 & Fusarium oxysporum & KU872849.1 \\
\hline M85 & $\mathrm{P}$ & Chissano/2014 & LPA 91 & Fusarium equiseti & KF918580.1 \\
\hline M86 & NP & Chissano/2014 & LPA 91 & Fusarium thapsinum & KX171659.1 \\
\hline M87 & NP & Chissano/2014 & LPA 91 & Fusarium thapsinum & KX171659.1 \\
\hline M88 & NP & Chissano/2014 & LPA 91 & Fusarium thapsinum & KM589051.1 \\
\hline M89 & $\mathrm{P}$ & Chissano/2014 & LPA 91 & Fusarium thapsinum & KM589051.1 \\
\hline M90 & $\mathrm{P}$ & Chissano/2014 & LPA 91 & Fusarium oxysporum & KU872849.1 \\
\hline M91 & $\mathrm{P}$ & Chissano/2014 & LPA 91 & Fusarium equiseti & KR094440.1 \\
\hline M92 & NP & Gurue/2014 & Kiangwe & Trichoderma harzianum & KR868296.1 \\
\hline M93 & NP & Gurue/2014 & Kiangwe & $\begin{array}{l}\text { Trichoderma } \\
\text { atrobrunneum }\end{array}$ & NR_137298.1 \\
\hline M94 & NP & Gurue/2014 & Kiangwe & Trichoderma harzianum & KR868296.1 \\
\hline M95 & NP & Gurue/2014 & Kiangwe & Trichoderma harzianum & HG940486.1 \\
\hline M96 & NP & Gurue/2014 & Kiangwe & Trichoderma harzianum & KR868309.1 \\
\hline M97 & NP & Gurue/2014 & Kiangwe & Trichoderma harzianum & KU696482.1 \\
\hline M98 & $\mathrm{P}$ & Gurue/2014 & Goloi & Fusarium proliferatum & KP760063.1 \\
\hline M99 & $\mathrm{P}$ & Gurue/2014 & Goloi & Fusarium circinatum & KC464621.1 \\
\hline M100 & $\mathrm{P}$ & Gurue/2014 & Goloi & Fusarium verticillioides & KX196811.1 \\
\hline M101 & $\mathrm{P}$ & Gurue/2014 & Goloi & Fusarium verticillioides & KX196811.1 \\
\hline M102 & $\mathrm{P}$ & Gurue/2014 & Kablanketi & Fusarium equiseti & EU625404.1 \\
\hline
\end{tabular}




\begin{tabular}{|c|c|c|c|c|c|}
\hline M103 & $\mathrm{P}$ & Gurue/2014 & Kablanketi & Fusarium incarnatum & KM921663.1 \\
\hline M104 & $\mathrm{P}$ & Gurue/2014 & Kablanketi & Fusarium equiseti & KR047055.1 \\
\hline M105 & $\mathrm{P}$ & Gurue/2014 & Kablanketi & Fusarium equiseti & KF863780.1 \\
\hline M106 & NP & Gurue/2014 & Kablanketi & Fusarium equiseti & KF863780.1 \\
\hline M107 & NP & Gurue/2014 & Kablanketi & Fusarium equiseti & HM008677.1 \\
\hline M108 & NP & Gurue/2014 & Kablanketi & Fusarium incarnatum & KU680357.1 \\
\hline M109 & NP & Gurue/2014 & Kablanketi & Fusarium equiseti & HM008677.1 \\
\hline M110 & $\mathrm{P}$ & Gurue/2014 & Sodan & Fusarium equiseti & KR094440.1 \\
\hline M111 & $\mathrm{P}$ & Gurue/2014 & Sodan & Fusarium equiseti & KR094440.1 \\
\hline M112 & $\mathrm{P}$ & Gurue/2014 & Sodan & Fusarium equiseti & KU856645.1 \\
\hline M113 & $\mathrm{P}$ & Gurue/2014 & Sodan & Fusarium equiseti & KU856645.1 \\
\hline M114 & $\mathrm{P}$ & Gurue/2014 & Sodan & Fusarium equiseti & KU856645.1 \\
\hline M115 & NP & Gurue/2014 & Sodan & Fusarium equiseti & KU856645.1 \\
\hline M116 & $\mathrm{P}$ & Gurue/2014 & Sodan & Fusarium equiseti & JQ936262.1 \\
\hline M117 & $\mathrm{P}$ & Gurue/2014 & Sodan & Fusarium equiseti & JQ936262.1 \\
\hline M118 & $\mathrm{P}$ & Gurue/2014 & G5087 & Nectria haematococca & KJ780750.1 \\
\hline M119 & $\mathrm{P}$ & Gurue/2014 & G5087 & Fusarium oxysporum & KP050556.1 \\
\hline M120 & $\mathrm{P}$ & Gurue/2014 & G5087 & Fusarium oxysporum & HQ439152.1 \\
\hline M121 & $\mathrm{P}$ & Gurue/2014 & G5087 & Fusarium oxysporum & JN006816.1 \\
\hline M122 & $\mathrm{P}$ & Gurue/2014 & G5087 & Fusarium oxysporum & HQ439152.1 \\
\hline M123 & NP & Gurue/2014 & G5087 & Fusarium oxysporum & KX196809.1 \\
\hline M124 & NP & Gurue/2014 & G5087 & Fusarium oxysporum & KT223349.1 \\
\hline M125 & $\mathrm{P}$ & Gurue/2014 & G5087 & Fusarium solani & EU625405.1 \\
\hline M126 & NP & Gurue/2014 & G5087 & Fusarium oxysporum & KX196809.1 \\
\hline M127 & $\mathrm{P}$ & Gurue/2014 & G5087 & Fusarium oxysporum & KC202939.1 \\
\hline M128 & $\mathrm{P}$ & Gurue/2014 & G5087 & Fusarium oxysporum & KM817209.1 \\
\hline M129 & $\mathrm{P}$ & Gurue/2014 & G5087 & Fusarium oxysporum & KU931543.1 \\
\hline
\end{tabular}




\begin{tabular}{|c|c|c|c|c|c|}
\hline M130 & $\mathrm{P}$ & Gurue/2014 & G5087 & Fusarium solani & JN006816.1 \\
\hline M131 & $\mathrm{P}$ & Gurue/2014 & CAL 143 & Fusarium solani & KU377510.1 \\
\hline M132 & $\mathrm{P}$ & Gurue/2014 & CAL 143 & Fusarium solani & JQ277276.1 \\
\hline M133 & $\mathrm{P}$ & Gurue/2014 & CAL 143 & Fusarium oxysporum & KM817213.1 \\
\hline M134 & $\mathrm{P}$ & Gurue/2014 & CAL 143 & Fusarium oxysporum & KJ082096.1 \\
\hline M135 & $\mathrm{P}$ & Gurue/2014 & G22246 & Fusarium oxysporum & GQ131884.1 \\
\hline M136 & $\mathrm{P}$ & Gurue/2014 & G22246 & Fusarium oxysporum & GQ131884.1 \\
\hline M137 & $\mathrm{P}$ & Gurue/2014 & G22246 & Fusarium oxysporum & KF498869.1 \\
\hline M138 & $\mathrm{P}$ & Gurue/2014 & G22246 & Fusarium oxysporum & KC202939.1 \\
\hline M139 & $\mathrm{P}$ & Gurue/2014 & G22246 & Fusarium oxysporum & KU931543.1 \\
\hline M140 & $\mathrm{P}$ & Gurue/2014 & G22246 & Fusarium oxysporum & KU931543.1 \\
\hline M141 & $\mathrm{P}$ & Gurue/2014 & G22246 & Fusarium oxysporum & KJ562370.1 \\
\hline M142 & NP & Gurue/2014 & G22246 & Fusarium oxysporum & GQ131884.1 \\
\hline M143 & $\mathrm{P}$ & Gurue/2014 & Badillo & Fusarium oxysporum & KU931543.1 \\
\hline M144 & $\mathrm{P}$ & Gurue/2014 & Badillo & Fusarium oxysporum & KU931543.1 \\
\hline M145 & $\mathrm{P}$ & Gurue/2014 & Badillo & Fusarium oxysporum & KU931553.1 \\
\hline M146 & $\mathrm{P}$ & Gurue/2014 & Badillo & Fusarium oxysporum & KM817213.1 \\
\hline M147 & $\mathrm{P}$ & Gurue/2014 & Badillo & Fusarium oxysporum & HG423346.1 \\
\hline M148 & $\mathrm{P}$ & Gurue/2014 & Badillo & Fusarium oxysporum & KJ082096.1 \\
\hline M149 & $\mathrm{P}$ & Gurue/2014 & Badillo & Fusarium oxysporum & KU059956.1 \\
\hline M150 & $\mathrm{P}$ & Gurue/2014 & Badillo & Fusarium oxysporum & KU056819.1 \\
\hline M151 & $\mathrm{P}$ & Gurue/2014 & INIAP480 & Fusarium oxysporum & KR047056.1 \\
\hline M152 & $\mathrm{P}$ & Gurue/2014 & INIAP480 & Fusarium oxysporum & KU931543.1 \\
\hline M153 & $\mathrm{P}$ & Gurue/2014 & INIAP480 & Fusarium oxysporum & KU056819.1 \\
\hline M154 & NP & Gurue/2014 & INIAP480 & Fusarium equiseti & KU926350.1 \\
\hline M155 & $\mathrm{P}$ & Gurue/2014 & INIAP480 & $\begin{array}{l}\text { Fusarium oxysporum } \mathrm{f} \text {. } \\
\text { sp. vasinfectum }\end{array}$ & EU849584.1 \\
\hline M156 & $\mathrm{P}$ & Gurue/2014 & INIAP480 & Fusarium equiseti & JQ936262.1 \\
\hline
\end{tabular}




\begin{tabular}{|c|c|c|c|c|c|}
\hline M157 & $\mathrm{P}$ & Gurue/2014 & INIAP480 & Fusarium oxysporum & GQ131884.1 \\
\hline M158 & NP & Gurue/2014 & INIAP480 & Fusarium equiseti & JF773657.1 \\
\hline M159 & $\mathrm{P}$ & Gurue/2014 & INIAP480 & Fusarium oxysporum & GU724514.1 \\
\hline M160 & $\mathrm{P}$ & Gurue/2014 & Canioca/Kibala & Fusarium oxysporum & KU931543.1 \\
\hline M161 & $\mathrm{P}$ & Gurue/2014 & Canioca/Kibala & Fusarium oxysporum & KU931543.1 \\
\hline M162 & $\mathrm{P}$ & Gurue/2014 & Canioca/Kibala & $\begin{array}{l}\text { Fusarium oxysporum } \mathrm{f} \text {. } \\
\text { sp. vasinfectum }\end{array}$ & KU729045.1 \\
\hline M163 & $\mathrm{P}$ & Gurue/2014 & Canioca/Kibala & Fusarium oxysporum & KU931543.1 \\
\hline M164 & $\mathrm{P}$ & Gurue/2014 & Canioca/Kibala & Fusarium oxysporum & KU059956.1 \\
\hline M165 & $\mathrm{P}$ & Gurue/2014 & Canioca/Kibala & No similarity found & \\
\hline M166 & $\mathrm{P}$ & Gurue/2014 & Canioca/Kibala & Fusarium oxysporum & KF577910.1 \\
\hline M167 & NP & Gurue/2014 & ND061106 & Fusarium equiseti & KF863780.1 \\
\hline M168 & $\mathrm{P}$ & Gurue/2014 & ND061106 & Fusarium equiseti & KF863780.1 \\
\hline M169 & NP & Gurue/2014 & ND061106 & Fusarium equiseti & KR047055.1 \\
\hline M170 & $\mathrm{P}$ & Gurue/2014 & ND061106 & Fusarium equiseti & KF863780.1 \\
\hline M171 & $\mathrm{P}$ & Gurue/2014 & ND061106 & Fusarium oxysporum & KJ019830.1 \\
\hline M172 & $\mathrm{P}$ & Gurue/2014 & ND061106 & Fusarium solani & KU382502.1 \\
\hline M173 & $\mathrm{P}$ & Gurue/2014 & ND061106 & Fusarium proliferatum & KY590032.1 \\
\hline M174 & NP & Gurue/2014 & H9659-27-10 & Fusarium oxysporum & EU839377.1 \\
\hline M175 & $\mathrm{P}$ & Gurue/2014 & H9659-27-10 & Fusarium oxysporum & KT898585.1 \\
\hline M176 & NP & Gurue/2014 & H9659-27-10 & $\begin{array}{l}\text { Talaromyces } \\
\text { pinophilus }\end{array}$ & LT558962.1 \\
\hline M177 & NP & Gurue/2014 & H9659-27-10 & Penicillium pinophilum & FJ441618.1 \\
\hline M178 & $\mathrm{P}$ & Gurue/2014 & Krimson & $\begin{array}{l}\text { Fusarium } \\
\text { brachygibbosum }\end{array}$ & KF985966.1 \\
\hline M179 & $\mathrm{P}$ & Gurue/2014 & NE34-12-30 & $\begin{array}{l}\text { Fusarium oxysporum } \mathrm{f} . \\
\text { sp. momordicae }\end{array}$ & JN005749.1 \\
\hline M180 & $\mathrm{P}$ & Gurue/2014 & NE34-12-30 & Fusarium equiseti & KJ562376.1 \\
\hline M181 & NP & Gurue/2014 & NE34-12-30 & Fusarium oxysporum & KU931553.1 \\
\hline
\end{tabular}




\begin{tabular}{|c|c|c|c|c|c|}
\hline M182 & $\mathrm{P}$ & Gurue/2014 & NE34-12-30 & Fusarium oxysporum & KU984712.1 \\
\hline M183 & NP & Gurue/2014 & NE34-12-30 & Fusarium oxysporum & KU931554.1 \\
\hline M184 & $\mathrm{P}$ & Gurue/2014 & NE34-12-30 & $\begin{array}{l}\text { Fusarium oxysporum } \mathrm{f} . \\
\text { sp. dianthi }\end{array}$ & EF421235.1 \\
\hline M185 & $\mathrm{P}$ & Gurue/2014 & NE34-12-30 & Fusarium proliferatum & KT207283.1 \\
\hline M186 & $\mathrm{P}$ & Gurue/2014 & NE34-12-30 & Fusarium equiseti & KU680356.1 \\
\hline M187 & $\mathrm{P}$ & Gurue/2014 & NE34-12-30 & Fusarium oxysporum & HF566400.1 \\
\hline M188 & $\mathrm{P}$ & Gurue/2014 & NE34-12-30 & Fusarium oxysporum & KU931543.1 \\
\hline M189 & $\mathrm{P}$ & Gurue/2014 & NE34-12-37 & Rhizoctonia solani & KM013470.1 \\
\hline M190 & $\mathrm{P}$ & Gurue/2014 & NE34-12-37 & Rhizoctonia solani & KM013470.1 \\
\hline M191 & $\mathrm{P}$ & Gurue/2014 & NE34-12-38 & Fusarium oxysporum & KJ528881.1 \\
\hline M192 & $\mathrm{P}$ & Gurue/2014 & NE34-12-38 & Fusarium oxysporum & KX196809.1 \\
\hline M193 & $\mathrm{P}$ & Gurue/2014 & NE34-12-38 & Fusarium oxysporum & KX196807.1 \\
\hline M194 & $\mathrm{P}$ & Gurue/2014 & NE34-12-38 & Fusarium oxysporum & KU056819.1 \\
\hline M195 & $\mathrm{P}$ & Gurue/2014 & NE34-12-48 & Fusarium oxysporum & KU056819.1 \\
\hline M196 & $\mathrm{P}$ & Gurue/2014 & NE34-12-48 & Fusarium oxysporum & GU181389.2 \\
\hline M197 & $\mathrm{P}$ & Gurue/2014 & NE34-12-48 & Fusarium oxysporum & KT207755.1 \\
\hline M198 & $\mathrm{P}$ & Gurue/2014 & NE34-12-48 & Fusarium oxysporum & KJ439149.1 \\
\hline M199 & NP & Gurue/2014 & RR372 & Fusarium solani & KJ528882.1 \\
\hline M200 & NP & Gurue/2014 & Manteiga & Cochliobolus sativus & JQ753975.1 \\
\hline M201 & $\mathrm{P}$ & Gurue/2014 & Manteiga & Fusarium equiseti & KU856645.1 \\
\hline M202 & $\mathrm{P}$ & Gurue/2014 & Manteiga & Fusarium oxysporum & KM817213.1 \\
\hline M203 & $\mathrm{P}$ & Gurue/2014 & Manteiga & Fusarium equiseti & KU856645.1 \\
\hline M204 & $\mathrm{P}$ & Gurue/2014 & Manteiga & Fusarium thapsinum & KU680377.1 \\
\hline M205 & NP & Gurue/2014 & Manteiga & Fusarium thapsinum & KU680377.1 \\
\hline M206 & NP & Gurue/2014 & Manteiga & Fusarium equiseti & KU680356.1 \\
\hline M207 & NP & Gurue/2014 & Manteiga & Fusarium oxysporum & KU056816.1 \\
\hline M208 & $\mathrm{P}$ & Gurue/2014 & Manteiga & Fusarium oxysporum & KU056819.1 \\
\hline
\end{tabular}




\begin{tabular}{|c|c|c|c|c|c|}
\hline M209 & $\mathrm{P}$ & Gurue/2014 & Manteiga & Fusarium oxysporum & KJ544916.1 \\
\hline M210 & $\mathrm{P}$ & Gurue/2014 & Manteiga & Fusarium oxysporum & KF278962.1 \\
\hline M211 & $P$ & Gurue/2014 & Manteiga & Fusarium oxysporum & KF278962.1 \\
\hline M212 & $\mathrm{P}$ & Gurue/2014 & Manteiga & Fusarium oxysporum & KX196807.1 \\
\hline M213 & $\mathrm{P}$ & Gurue/2014 & $\begin{array}{l}\text { VTTTG25 5-1- } \\
2\end{array}$ & Fusarium oxysporum & KU056819.1 \\
\hline M214 & $\mathrm{P}$ & Gurue/2014 & $\begin{array}{l}\text { VTTTG25 5-1- } \\
2\end{array}$ & Fusarium solani & KJ696540.1 \\
\hline M215 & $\mathrm{P}$ & Gurue/2014 & $\begin{array}{l}\text { VTTTG25 5-1- } \\
2\end{array}$ & Fusarium oxysporum & KT223349.1 \\
\hline M216 & $\mathrm{P}$ & Gurue/2014 & $\begin{array}{l}\text { VTTTG25 5-1- } \\
2\end{array}$ & Fusarium oxysporum & HF566400.1 \\
\hline M217 & $\mathrm{P}$ & Gurue/2014 & $\begin{array}{l}\text { VTTTG25 5-1- } \\
2\end{array}$ & Fusarium oxysporum & HM346538.1 \\
\hline M218 & $\mathrm{P}$ & Gurue/2014 & $\begin{array}{l}\text { VTTTG25 5-1- } \\
2\end{array}$ & Fusarium solani & HQ439152.1 \\
\hline M219 & $\mathrm{P}$ & Gurue/2014 & $\begin{array}{l}\text { VTTTG25 5-1- } \\
2\end{array}$ & Fusarium solani & KJ696540.1 \\
\hline M220 & $\mathrm{P}$ & Gurue/2014 & $\begin{array}{l}\text { VTTTG25 5-1- } \\
2\end{array}$ & Fusarium oxysporum & GU724514.1 \\
\hline M221 & $\mathrm{P}$ & Gurue/2014 & $\begin{array}{l}\text { VTTTG25 5-1- } \\
2\end{array}$ & $\begin{array}{l}\text { Fusarium oxysporum } \mathrm{f} . \\
\text { sp. ciceris }\end{array}$ & KM817208.1 \\
\hline M222 & NP & Gurue/2014 & $\begin{array}{l}\text { VTTTG25 5-1- } \\
2\end{array}$ & Fusarium oxysporum & HF566400.1 \\
\hline M223 & $\mathrm{P}$ & Gurue/2014 & $\begin{array}{l}\text { VTTTG25 5-1- } \\
2\end{array}$ & Fusarium solani & KM235740.1 \\
\hline M224 & $\mathrm{P}$ & Chokwe/2015 & INIAP414 & $\begin{array}{l}\text { Macrophomina } \\
\text { phaseolina }\end{array}$ & KU680393.1 \\
\hline M225 & $P$ & Chokwe/2015 & INIAP414 & $\begin{array}{l}\text { Macrophomina } \\
\text { phaseolina }\end{array}$ & KU856652.1 \\
\hline M226 & $P$ & Chokwe/2015 & INIAP414 & $\begin{array}{l}\text { Macrophomina } \\
\text { phaseolina }\end{array}$ & KF951750.1 \\
\hline M227 & $P$ & Chokwe/2015 & INIAP414 & $\begin{array}{l}\text { Macrophomina } \\
\text { phaseolina }\end{array}$ & KM519193.1 \\
\hline M228 & NP & Chokwe/2015 & NE34-12-28 & Phoma multirostrata & JN542527.1 \\
\hline M229 & NP & Chokwe/2015 & PI321094-D & Phoma multirostrata & JN542527.1 \\
\hline M230 & NP & Chokwe/2015 & PI321094-D & Phoma multirostrata & JN542527.1 \\
\hline
\end{tabular}




\begin{tabular}{|c|c|c|c|c|c|}
\hline M231 & NP & Chokwe/2015 & PI321094-D & Setosphaeria rostrata & KT265240.1 \\
\hline M232 & NP & Chokwe/2015 & PI321094-D & Peyronellaea glomerata & KR012905.1 \\
\hline M233 & NP & Chokwe/2015 & PI321094-D & Phoma sp. & KM979987.1 \\
\hline M234 & NP & Chokwe/2015 & Uyole 98 & Phoma multirostrata & KU529840.1 \\
\hline M235 & NP & Chokwe/2015 & Uyole 98 & Phoma multirostrata & KU529840.1 \\
\hline M236 & NP & Chokwe/2015 & Hutterite & Phoma multirostrata & KU529840.1 \\
\hline M237 & NP & Chokwe/2015 & Hutterite & Aspergillus calidoustus & HG964947.1 \\
\hline M238 & NP & Chokwe/2015 & NE34-12-50 & Setosphaeria rostrata & KT265240.1 \\
\hline M239 & NP & Chokwe/2015 & NE34-12-50 & Setosphaeria rostrata & KT265240.1 \\
\hline M240 & $\mathrm{P}$ & Chokwe/2015 & NE34-12-50 & Fusarium oxysporum & KJ082096.1 \\
\hline M241 & $\mathrm{P}$ & Chokwe/2015 & NE34-12-50 & Fusarium solani & KM235740.1 \\
\hline M242 & $\mathrm{P}$ & Chokwe/2015 & PI321094-D & $\begin{array}{l}\text { Macrophomina } \\
\text { phaseolina }\end{array}$ & HM990163.1 \\
\hline M243 & $\mathrm{P}$ & Chokwe/2015 & PI321094-D & $\begin{array}{l}\text { Macrophomina } \\
\text { phaseolina }\end{array}$ & FJ643531.1 \\
\hline M244 & NP & Chokwe/2015 & PI321094-D & Phoma multirostrata & JN542527.1 \\
\hline M245 & $\mathrm{P}$ & Chokwe/2015 & PI321094-D & $\begin{array}{l}\text { Macrophomina } \\
\text { phaseolina }\end{array}$ & HQ649831.1 \\
\hline M246 & $\mathrm{P}$ & Chokwe/2015 & Kiangwe & Fusarium oxysporum & KM268692.1 \\
\hline M247 & $\mathrm{P}$ & Chokwe/2015 & Kiangwe & Fusarium solani & KM235740.1 \\
\hline M248 & NP & Chokwe/2015 & & Alternaria alternata & KP271958.1 \\
\hline M249 & NP & Chokwe/2015 & Hutterite & Curvularia hawaiiensis & HG778990.1 \\
\hline M250 & NP & Chokwe/2015 & Hutterite & Alternaria alternata & KU059951.1 \\
\hline M251 & $\mathrm{P}$ & Chokwe/2015 & $\begin{array}{l}\text { RR 375- Local } \\
\text { Check }\end{array}$ & $\begin{array}{l}\text { Macrophomina } \\
\text { phaseolina }\end{array}$ & KM519193.1 \\
\hline M252 & $\mathrm{P}$ & Chokwe/2015 & $\begin{array}{l}\text { RR 375- Local } \\
\text { Check }\end{array}$ & Fusarium equiseti & EU326202.1 \\
\hline M253 & $\mathrm{P}$ & Chokwe/2015 & $\begin{array}{l}\text { RR 375- Local } \\
\text { Check }\end{array}$ & Fusarium oxysporum & KJ207391.1 \\
\hline M254 & $\mathrm{P}$ & Chokwe/2015 & $\begin{array}{l}\text { RR 375- Local } \\
\text { Check }\end{array}$ & Fusarium equiseti & KR094440.1 \\
\hline
\end{tabular}




\begin{tabular}{|c|c|c|c|c|c|}
\hline M255 & $\mathrm{P}$ & Chokwe/2015 & $\begin{array}{l}\text { RR 375- Local } \\
\text { Check }\end{array}$ & Fusarium solani & KM235740.1 \\
\hline M256 & $\mathrm{P}$ & Chokwe/2015 & G10994 & Fusarium equiseti & KR094440.1 \\
\hline M257 & $\mathrm{P}$ & Chokwe/2015 & G10994 & Alternaria alternata & KF669893.1 \\
\hline M258 & $P$ & Chokwe/2015 & G10994 & Alternaria alternata & KP003824.1 \\
\hline M259 & $P$ & Chokwe/2015 & G10994 & Fusarium equiseti & KR094440.1 \\
\hline M260 & $\mathrm{P}$ & Chokwe/2015 & G10994 & Setosphaeria rostrata & KT265240.1 \\
\hline M261 & $\mathrm{P}$ & Chokwe/2015 & G22246 & Phaeosphaeriopsis sp. & JQ936185.1 \\
\hline M262 & $P$ & Chokwe/2015 & G22246 & Phoma multirostrata & JN542527.1 \\
\hline M263 & $\mathrm{P}$ & Chokwe/2015 & G22246 & Fusarium oxysporum & KJ082096.1 \\
\hline M264 & $\mathrm{P}$ & Chokwe/2015 & $\mathrm{G} 22246$ & Phoma sp. & KM516291.1 \\
\hline M265 & $\mathrm{P}$ & Chokwe/2015 & G22246 & Phoma multirostrata & KU529840.1 \\
\hline M266 & $\mathrm{P}$ & Chokwe/2015 & G22246 & Fusarium oxysporum & KJ082096.1 \\
\hline M267 & $\mathrm{P}$ & Chokwe/2015 & G17913 & $\begin{array}{l}\text { Macrophomina } \\
\text { phaseolina }\end{array}$ & KU863545.1 \\
\hline M268 & $\mathrm{P}$ & Chokwe/2015 & G10994 & Fusarium equiseti & KR094440.1 \\
\hline M269 & $\mathrm{P}$ & Chokwe/2015 & G10994 & $\begin{array}{l}\text { Macrophomina } \\
\text { phaseolina }\end{array}$ & KU856652.1 \\
\hline M270 & $\mathrm{P}$ & Chokwe/2015 & G10994 & $\begin{array}{l}\text { Macrophomina } \\
\text { phaseolina }\end{array}$ & HM990163.1 \\
\hline M271 & NP & Chokwe/2015 & G10994 & Chaetomium sp. & HQ608145.1 \\
\hline M272 & NP & Chokwe/2015 & G10994 & Chaetomium sp. & HQ608145.1 \\
\hline M273 & $\mathrm{P}$ & Chokwe/2015 & G22246 & Fusarium solani & JN006817.1 \\
\hline M274 & $\mathrm{P}$ & Chokwe/2015 & $\mathrm{G} 22246$ & Fusarium oxysporum & EU888922.1 \\
\hline M275 & $P$ & Gurue/2015 & Kiangwe & Fusarium equiseti & KX196808.1 \\
\hline M276 & $\mathrm{P}$ & Gurue/2015 & Kasukanywele & Fusarium oxysporum & KX196809.1 \\
\hline M277 & $\mathrm{P}$ & Gurue/2015 & Kasukanywele & Fusarium solani & KJ620369.1 \\
\hline M278 & $\mathrm{P}$ & Gurue/2015 & SUG-131 & $\begin{array}{l}\text { Pythium ultimum var. } \\
\text { sporangiiferum }\end{array}$ & AJ628986.1 \\
\hline
\end{tabular}




\begin{tabular}{|c|c|c|c|c|c|}
\hline M279 & $\mathrm{P}$ & Gurue/2015 & SUG-131 & Fusarium equiseti & KX196808.1 \\
\hline M280 & $\mathrm{P}$ & Gurue/2015 & SUG-131 & Fusarium equiseti & KR094440.1 \\
\hline M281 & NP & Gurue/2015 & G1375 & Fusarium equiseti & KR094440.1 \\
\hline M282 & NP & Gurue/2015 & G1375 & Phoma sp. & JQ388278.1 \\
\hline M283 & $\mathrm{P}$ & Gurue/2015 & G1375 & Epicoccum sorghinum & KX289695.1 \\
\hline M284 & $\mathrm{P}$ & Gurue/2015 & G1375 & Fusarium oxysporum & EU839378.1 \\
\hline M285 & $\mathrm{P}$ & Gurue/2015 & G10994 & Fusarium equiseti & KR364597.1 \\
\hline M286 & $\mathrm{P}$ & Gurue/2015 & G22246 & Fusarium solani & EU625405.1 \\
\hline M287 & $\mathrm{P}$ & Gurue/2015 & $\begin{array}{l}\text { Larga } \\
\text { Commercial }\end{array}$ & Fusarium equiseti & KX196808.1 \\
\hline M288 & NP & Gurue/2015 & $\begin{array}{l}\text { Larga } \\
\text { Commercial }\end{array}$ & Rhizoctonia solani & KF372651.1 \\
\hline M289 & $\mathrm{P}$ & Gurue/2015 & $\begin{array}{l}\text { Larga } \\
\text { Commercial }\end{array}$ & Fusarium oxysporum & KJ082096.1 \\
\hline M290 & NP & Gurue/2015 & $\begin{array}{l}\text { Larga } \\
\text { Commercial }\end{array}$ & Fusarium oxysporum & GU724513.1 \\
\hline M291 & $\mathrm{P}$ & Gurue/2015 & $\begin{array}{l}\text { Larga } \\
\text { Commercial }\end{array}$ & Epicoccum sorghinum & KX289695.1 \\
\hline M292 & $\mathrm{P}$ & Gurue/2015 & $\begin{array}{l}\text { Larga } \\
\text { Commercial }\end{array}$ & Alternaria alternata & KM519671.1 \\
\hline M293 & NP & Gurue/2015 & $\begin{array}{l}\text { Larga } \\
\text { Commercial }\end{array}$ & Fusarium equiseti & KX196808.1 \\
\hline M294 & NP & Gurue/2015 & $\begin{array}{l}\text { Larga } \\
\text { Commercial }\end{array}$ & Fusarium oxysporum & KF577910.1 \\
\hline M295 & $\mathrm{P}$ & Gurue/2015 & $\begin{array}{l}\text { Larga } \\
\text { Commercial }\end{array}$ & No similarity found & \\
\hline M296 & $\mathrm{P}$ & Gurue/2015 & INIAP-414 & Fusarium oxysporum & GU724513.1 \\
\hline M297 & $\mathrm{P}$ & Gurue/2015 & INIAP-414 & Rhizoctonia solani & KF372651.1 \\
\hline M298 & NP & Gurue/2015 & INIAP-414 & Rhizoctonia solani & KF372652.1 \\
\hline M299 & NP & Gurue/2015 & INIAP-414 & Phoma herbarum & KU529842.1 \\
\hline M300 & NP & Gurue/2015 & INIAP-414 & Cladorrhinum samala & FM955447.1 \\
\hline M301 & NP & Gurue/2015 & INIAP-414 & Phoma sp. & JQ388278.1 \\
\hline M302 & $\mathrm{P}$ & Gurue/2015 & INIAP-414 & Fusarium proliferatum & KJ528883.1 \\
\hline M303 & $\mathrm{P}$ & Gurue/2015 & INIAP-414 & Fusarium oxysporum & KX196809.1 \\
\hline
\end{tabular}




\begin{tabular}{|c|c|c|c|c|c|}
\hline M304 & $\mathrm{P}$ & Gurue/2015 & INIAP-414 & Fusarium oxysporum & KX196809.1 \\
\hline M305 & NP & Gurue/2015 & INIAP-414 & Phoma herbarum & KU529842.1 \\
\hline M306 & $\mathrm{P}$ & Gurue/2015 & INIAP-414 & Fusarium verticillioides & KU680389.1 \\
\hline M307 & $\mathrm{P}$ & Gurue/2015 & INIAP-414 & Fusarium oxysporum & KX196809.1 \\
\hline M308 & NP & Gurue/2015 & INIAP-414 & Epicoccum sorghinum & KT310093.1 \\
\hline M309 & $\mathrm{P}$ & Gurue/2015 & INIAP-414 & Fusarium verticillioides & KU680389.1 \\
\hline M310 & $\mathrm{P}$ & Gurue/2015 & INIAP-414 & Fusarium oxysporum & GU724514.1 \\
\hline M311 & $\mathrm{P}$ & Gurue/2015 & INIAP-414 & Fusarium oxysporum & KX196809.1 \\
\hline M312 & $\mathrm{P}$ & Gurue/2015 & PI321094-D & Fusarium solani & KU377510.1 \\
\hline M313 & $\mathrm{P}$ & Gurue/2015 & PI321094-D & $\begin{array}{l}\text { Fusarium oxysporum } \mathrm{f} . \\
\text { sp. ciceris }\end{array}$ & KR364590.1 \\
\hline M314 & NP & Gurue/2015 & NE34-12-28 & Fusarium oxysporum & GU724513.1 \\
\hline M315 & $\mathrm{P}$ & Gurue/2015 & NE34-12-28 & Fusarium equiseti & KF863780.1 \\
\hline M316 & NP & Gurue/2015 & NE34-12-28 & Epicoccum sorghinum & KX289695.1 \\
\hline M317 & NP & Gurue/2015 & NE34-12-28 & Alternaria alternata & KT223359.1 \\
\hline M318 & $\mathrm{P}$ & Gurue/2015 & NE34-12-28 & Fusarium oxysporum & GU724514.1 \\
\hline M319 & $\mathrm{P}$ & Gurue/2015 & A222 & $\begin{array}{l}\text { Fusarium oxysporum } \mathrm{f} . \\
\text { sp. vanillae }\end{array}$ & KM005080.1 \\
\hline M320 & $\mathrm{P}$ & Gurue/2015 & A222 & Fusarium oxysporum & JF440593.1 \\
\hline M321 & NP & Gurue/2015 & A222 & Fusarium oxysporum & EU326216.1 \\
\hline M322 & $\mathrm{P}$ & Gurue/2015 & A222 & $\begin{array}{l}\text { Fusarium oxysporum } \mathrm{f} . \\
\text { sp. ciceris }\end{array}$ & KR364590.1 \\
\hline M323 & $\mathrm{P}$ & Gurue/2015 & Magnum & Fusarium oxysporum & KX834820.1 \\
\hline M324 & $\mathrm{P}$ & Gurue/2015 & Magnum & Fusarium solani & JN006817.1 \\
\hline M325 & $\mathrm{P}$ & Gurue/2015 & Magnum & $\begin{array}{l}\text { Macrophomina } \\
\text { phaseolina }\end{array}$ & HQ649832.1 \\
\hline M326 & NP & Gurue/2015 & Magnum & Rhizoctonia solani & JF701745.1 \\
\hline M327 & $\mathrm{P}$ & Gurue/2015 & Magnum & $\begin{array}{l}\text { Macrophomina } \\
\text { phaseolina }\end{array}$ & KM979991.1 \\
\hline
\end{tabular}




\begin{tabular}{|l|l|l|l|l|l|}
\hline M328 & NP & Gurue/2015 & Magnum & Pleosporaceae sp. & HQ832799.1 \\
\hline M329 & $\mathrm{P}$ & Gurue/2015 & Kiangwe & Fusarium proliferatum & KU680369.1 \\
\hline M330 & $\mathrm{P}$ & Gurue/2015 & Kiangwe & No similarity found & \\
\hline M331 & $\mathrm{P}$ & Gurue/2015 & NE34-12-50 & Fusarium falciforme & KC254047.1 \\
\hline M332 & $\mathrm{P}$ & Gurue/2015 & NE34-12-50 & Fusarium oxysporum & EF495235.1 \\
\hline M333 & $\mathrm{P}$ & Gurue/2015 & NE34-12-50 & Fusarium solani & FJ478114.1 \\
\hline
\end{tabular}

aP-Pathogenic; NP-Non-pathogenic

${ }^{b}$ Query cover $>99 \%$. Identity $97-1$ 